\title{
South African inquiries into policing, 1910-2015
}

\section{Annie Kok and Elrena van der Spuy}

Centre of Criminology

University of Cape Town

\section{Contents}

Introduction

Inquiries

Report of the Witwatersrand Disturbances Commission

Report of the Commission appointed to enquire into Assaults on Women .......................................................................

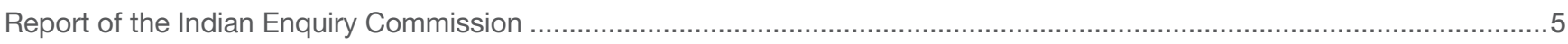

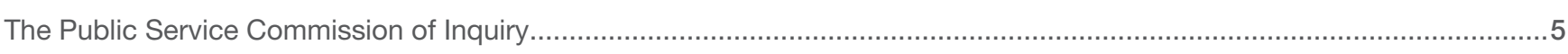

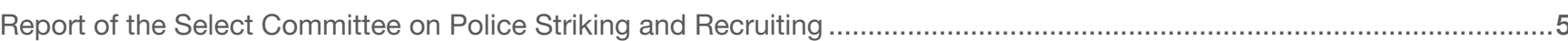

Report of the Commissioner appointed to hold an enquiry regarding alleged ill-treatment of natives by members of the police force during the recent native unrest at Johannesburg

Report of the commissioners appointed to enquire into the causes of, and occurrences at, the native disturbance at Port Elizabeth on 23 October 1920, and the general economic conditions as they affect the native and coloured population........6 Interim and Final Reports of the Native Affairs Commission and telegram from Commissioner, South African Police, relative to 'Israelites' at Bulhoek and Occurrences in May 1921.

Report of the Commission appointed to enquire into the Rebellion of the Bondelzwarts .....................................................

Commission of Inquiry into Native riots at Bloemfontein

Report of the Commission of Enquiry into the organisation of the South African Police Force, Established under Act No. 14 of 1912

Report of the Commission of Enquiry into the Native Riots at Durban on the $17^{\text {th }}$ and $18^{\text {th }}$ June 1929

Interim and Final Reports of the Commission of Inquiry to inquire into certain matters concerning the South African Police and the South African Railways and Harbours Police. 
Report of the Commission appointed to enquire into the riots which took place in Johannesburg on 31 January 1941, and 1 February 1941

Judicial Commission of Enquiry - Pretoria municipal riot of 28 December 1942 Report

.9

Report of the Commission to enquire into the disturbances of the $30^{\text {th }}$ August, 1947, at the Moroka Emergency Camp, Johannesburg

Report of Commission of Enquiry into Riots in Durban

Report of the Commission appointed to enquire into Acts of Violence Committed by Natives at Krugersdorp, Newlands,

Randfontein, and Newclare

Report of the Commission of Enquiry into Allegations against Members of the South African Police....

Report of the Commission of Enquiry into the Disturbances in the Witzieshoek Native Reserve

Report of the Departmental Committee of enquiry on Pensions (South African Police Force).

Report of the Commission appointed by the City Council of Johannesburg to enquire into the causes and circumstances of the riots which took place in the vicinity of the Dube Hostel in the South-Western Native Township over the weekend 14/15 September 1957

Report of the Commission Appointed to Investigate and Report on the Occurrences in the Districts of Vereeniging, namely at Sharpeville Location, and Evaton, and Vanderbijlpark, Province of the Transvaal, on $21^{\text {st }}$ March, 1960

Report of the Commission of enquiry into the events in Langa Location, district of Wynberg, Cape of Good Hope, on $21^{\text {st }}$ March 1960

Interim and Final Report of the Commission to inquire into the events at Paarl and the causes which gave rise thereto........14 Interim Report of the Commission of Inquiry into matters relating to the Security of the State

Final Report of the Commission of Inquiry into matters relating to the Security of the State......

Report of the Commission of Inquiry into certain matters relating to the University of the North

Report of the Commission of Inquiry into the Riots at Soweto and elsewhere from the 16 of June 1976 to 28 of

February 1977

Commission of Inquiry into Reporting on Security Matters regarding the South African Defence Force and the South African Police .....

Report of the Commission of Inquiry into the Violence which occurred on 29 October 1983 at the University of Zululand (Vol. 1 \& 2) 
Report of the Commission appointed to inquire into the Incident which occurred on 21 March 1985 at Uitenhage.

The Commission of Inquiry into the 1986 Unrest and Alleged Mismanagement in KwaNdebele.....

Report of the Commission of Enquiry into the cause of the unrest in Venda during August 1988 and the investigation of ritual murders

Report of the Commission of Enquiry into the incidents at Sebokeng, Boipatong, Lekoa, Sharpeville and Evaton on 26 March 1990

Report of the Commission of Inquiry into certain Alleged Murders

Report of Commission of Inquiry into Activities of Police and Military Relative to the Teachers' strike..... 18

Commission of Inquiry regarding the Prevention of Public Violence and Intimidation

Commission of Inquiry into the incidents that led to the violence in the former Bophuthatswana on 11 March 1994, and the deaths that occurred as a result thereof ...

Report by the South African Human Rights Commission Inquiry into racism in the SAPS Vryburg District....

Commission of Inquiry into the mandate and location of the Directorate of Special Operations ('the DSO')

South African Human Rights Commission report: In the matter between Council for the Advancement of the SA Constitution and South African Police Service.....

Report of the Commission of Inquiry into Allegations of Police inefficiency and a Breakdown in Relations between SAPS and the Community of Khayelitsha

Marikana Commission of Inquiry Report on matters of public, national and international concern arising out of the tragic Incidents at the Lonmin mine in Marikana, in the North West Province.

Inquiries into policing in South Africa: A brief overview 


\section{South African inquiries into policing, 1910-2015}

In the last three years attention has focused on two commissions of inquiry into police conduct, namely the Khayelitsha and Marikana commissions. These investigations have reinvigorated discussions on safety, the role and capacity of the police, and the policy challenges ahead. Stepping back

from the immediacy of the moment, it is perhaps timely to ask about the role of inquiries into police over a longer time frame. In search of an answer to this question Annie Kok, a post-graduate student attached to the Centre of Criminology, went in search of some answers. The hunt for other inquiries

proved both exhilarating and frustrating. We relied on our understanding of critical moments in South Africa's political history, electronic searches of various databases, and archival

sources housed in various localities. The search yielded no fewer than 44 inquiries between 1910 and 2015 in which the police featured in one or another critical way. The data have been collated into a tabular format. The Institute of Security Studies has offered to make this electronic resource available as an addendum to the recently published special edition of the South African Crime Quarterly 53 of September 2015. This electronic resource should be seen as a work in progress to which others may wish to contribute.
Public inquiries come in many shapes and forms, for example royal commissions of inquiry, statutory inquiries, select committee inquiries undertaken under the auspices of Parliament, ombudsman inquiries and ministerial inquiries.

The concept 'commission of inquiry' should be understood as a generic term used to describe an ad hoc and independent institution established by the government or a minister to investigate particular issues or past events by gathering evidence in a public manner. In the South African case, the Commissions Act 1947 (Act 8 of 1947) provides the legal terms of reference for the establishment and functioning of such public inquiries.

The information collated in this document demonstrates that inquiries have a long history in South Africa. In fact, over the past 100 years inquiries into the police have been invoked with regularity. The 44 inquiries straddle the different historical periods constitutive of modern South Africa. Closer scrutiny of these inquiries reveals both continuities and differences in their forms and substantive concerns.

It would appear that inquiries have coalesced around four broad thematic areas of inquiry. The first theme concerns administrative matters. Throughout the period under consideration, a number of inquiries have been used to investigate administrative concerns. Examples include the 1918 Select Committee Inquiry, which investigated conditions of service after a police strike in Cape Town. In 1926 the Te Water Commission of Inquiry examined the organisational structure of the South African Police (SAP) and matters relating to police image and morale. In 1937 the Lansdown
Commission of Inquiry conducted a comprehensive investigation into the general conditions of service prevailing within the SAP. Included in this review were the ways in which racial discrimination had an effect on black members of the force and the impact of racial politics on external relations with the disenfranchised. From a historical angle one is well placed to note that administrative questions relating to resources, capacity, efficiency and community police relations, as explored in the Khayelitsha Commission of 2012, reflect long-standing concerns that have been examined by inquiries in earlier periods.

\section{From the international record we know that corruption scandals act as powerful \\ triggers for establishing inquiries}

A second theme to which inquiries have responded relates to allegations of corruption. From the international record we know that corruption scandals act as powerful triggers for establishing inquiries. Take the New York City Police Department, for example. Between 1894 and 1994 no fewer than six commissions of inquiry have investigated corruption within its ranks. The Mollen Commission of 1994 is particularly well known. Its report made an important contribution to our understanding of the external and internal environments within which organisational corruption flourishes. In the South African case, the establishment of the Lansdown Commission of 1937 (mentioned earlier) was prompted by allegations of police corruption. A decade later the Hoexter Commission 
(1950) also turned its attention to bribery and corruption in the Johannesburg area, relating specifically to the provision of liquor licences.

A third theme, which presents itself in the late 1980s history of South African policing, is investigations into police collusion in political violence. A case in point is the Harms Commission of Inquiry, established in 1990 to investigate allegations of officially authorised and funded police death squads. Its report, which was released in November 1990, failed to name any specific army or police units, or individual officers, as participants in death squads. It was widely denounced by opposition groups. Many considered the work of this commission to be flawed in both design and practice. A year later, under different political conditions, then-president

FW de Klerk appointed the Goldstone Commission of Inquiry regarding the Prevention of Public Violence and Intimidation.

For two years it examined various aspects of security conduct as well as involvement in political violence. (Thirdforce activity also resurfaced in the deliberations of the Truth and Reconciliation Commission of 1996. This commission, however, has not been included here.)

\section{The historical record provides abundant examples of the conflictual nature of the interactions between the state and, in most instances, the disenfranchised}

A fourth - and dominant - theme concerns the conduct of police in the context of disturbances, protest actions and riots. Police conduct in terms of public disorder is, in fact, the concern of a large number of inquiries. In different places and at different times crowds of people would assemble to express their concerns and frustrations and voice their aspirations. The triggers for these gatherings varied from hut and poll taxes, restrictions on the production and consumption of liquor or discriminatory labour practices to the enforcement of pass laws, police brutality or, as in the case of Soweto in 1976, the imposition of Afrikaans as a medium of instruction in the so-called Bantu education system. In all of the situations groups of people (often called 'mobs') would gather in localities both urban and rural, more or less spontaneously and more or less peacefully. Before long these gatherings would confront pockets of police.

The police too may have been more or less organised to deal with the 'situation'. Soon the mood between the two adversaries would turn acrimonious. Insults would be traded and provocations exchanged. The action or reaction of the police would as a matter of default be steeped in the logic of paramilitary defence of 'state security'.

The historical record provides abundant examples of the conflictual nature of the interactions between the state and, in most instances, the disenfranchised. Included on this list are the interaction between the Israelite sect and the police at Bulhoek (1921); the rebellion of the Bondelzwarts people (1922); and the riots in Bloemfontein (1925), Durban (1929 and 1949), Vereeniging (1937), Johannesburg (1941), Pretoria (1942), Moroka Camp in Kliptown (1947), Krugersdorp (1949), Witzieshoek Native Reserve (1951) and Dube hostel (1958). Thereafter the bloodied events in Sharpeville (1960) and Soweto (1976) would solicit international condemnation of the repressive politics of the apartheid police.

Concerns about security force conduct under successive states of emergency would grow in the 1980s. Between 1980 and 1992, in the context of a widening of mass resistance and state repression (as the information collated in the table makes clear), many more incidents were subjected to public inquiries. As political negotiations got underway the Goldstone Commission was established. Its terms of reference were wide. In the course of its three-year existence it investigated a large number of violent incidents in which the police played some kind of role. A total of 47 reports were compiled by 
the Goldstone Commission, of which a significant proportion focussed on the police and military.

An historical overview reveals the structural disposition toward confrontation, skirmishes and violence, resulting in injuries and deaths, between the police and the citizenry. Incidents of police brutality and the police's use of lethal force against striking workers at Lonmin mine in 2012, for example, are contemporary manifestations of a much older theme.

\section{The repetitive and cyclical nature of commissions of inquiry has prompted Limieux to invoke the metaphor of a circus}

Commissions of inquiry, as Adam Ashforth has argued, are worthy objects of inquiry themselves. They all embark on labour-intensive processes of fact-finding fitted to their respective terms of reference. Data would have to be collected; public hearings held at which testimonies are given and expert evidence considered. Once fact-finding is concluded the inquiries would enter the next phase of the life of a commission, where reports are drafted and eventually submitted. The reports would offer a reconstruction of the events that were investigated. Such reports would indicate where appropriate blame should be apportioned and people or institutions exonerated. Many of the commissions would identify the administrative and/or systemic weaknesses to which constructive recommendations may be added. The findings of the reports would make their way into the public domain. Dialogue on the findings may prove instrumental for raising public awareness about issues of national concern. At the end of all these efforts we enter the archival phase. At this point the wealth of data, consisting of reports, transcriptions, video recordings and visual images, will be deposited in an archival space. There the report may gather considerable dust, only to be rediscovered at some later point in time.
The repetitive and cyclical nature of commissions of inquiry has prompted Limieux ${ }^{2}$ to invoke the metaphor of a circus. He puts it as follows:

Commissions of Inquiry remind me of a circus. In European films such as Jacques Tati's Jour de Fete, Gunther Grass's The Tin Drum and Fellini's The Clown, we see the excitement and expectation building up in the town, the big parade of clowns, jugglers, and animals. Then the show begins. Children are given balloons, members of the audience are invited to come on the stage to take part in some acts, people shout, cry, or clap their hands. Then, the following night, the circus leaves town and disappears without a trace, like a fading star.

Using Limieux's metaphor one is tempted to conclude that South Africans have had ample opportunity to visit the roving circuses that have been convened by a staggering number of inquiries into incidences in which police were implicated. Have we utilised the opportunities to learn that commissions afford us? The answer to this question awaits further research. In pursuit of answers to the question about the impact of inquiries we should situated inquiries in their historical context and be willing to engage with them in comparative ways. Furthermore, we should examine the social and political interests at stake and the contestations to which competing interests give rise. Finally, we should engage critically with the ways in which inquiries re-construct the world and through such construction lay claim to knowledge production. It is when we turn inquiries into objects of critical analysis that we can investigate not only what they reveal about the world but also what they leave concealed.

\section{Notes}

A Ashforth, Reckoning schemes of legitimation: commissions of inquiry as power/knowledge forms, Journal of Historical Sociology, 3:1, 1990, $1-22$

2 D Limieux, Commentary, in A Mason and D Mullan (eds), Commissions of Inquiry: Praise or Reappraise? Toronto: Irwin Law, 2003. 


\begin{tabular}{|c|c|c|c|c|c|c|c|c|c|c|c|}
\hline Inquiry name & Date & Reference & Type of inquiry & Chairperson & \multicolumn{7}{|c|}{ Commissioner(s) } \\
\hline \multirow{4}{*}{$\begin{array}{l}\text { Report of the } \\
\text { Witwatersrand } \\
\text { Disturbances } \\
\text { Commission }\end{array}$} & Established: July 1913 & \multirow{2}{*}{$\begin{array}{c}\text { Cd } 7112 \\
\text { UG 56/1913 (minutes) }\end{array}$} & \multirow{2}{*}{$\begin{array}{l}\text { Judicial Commission } \\
\text { of Inquiry }\end{array}$} & Sir Johannes W Wessels & \multicolumn{7}{|c|}{ Charles G Ward } \\
\hline & Finalised: Sept 1913 & & & Judge & \multicolumn{7}{|c|}{ Judge } \\
\hline & Terms of reference & \multicolumn{10}{|c|}{$\begin{array}{l}\text { 'To inquire into and report upon the following: } \\
\text { (1) The causes leading to public disorder during the period of } 13 \text { June } 1913 \text { to } 5 \text { July } 1913 . \\
\text { (2) What steps were taken to alleviate the differences that arose between the New Kleinfontein Gold Mining Company, Limited, and } \\
\text { its employees? } \\
\text { (3) Was it necessary for the Government to take special precautions to preserve and restore order and to protect life and property? } \\
\text { (4) Was it necessary for the government to deploy Military Forces? } \\
\text { (5) Was the public disorder such as to justify the Police, Defence and the Military Forces to use forcible methods, including the use } \\
\text { of firearms? } \\
\text { Did these aforementioned agencies use unnecessary force to preserve and restore order and to protect life and property?' }\end{array}$} \\
\hline & Context & \multicolumn{10}{|c|}{$\begin{array}{l}\text { What started as a small underground strike among mechanics transformed into a general strike across the Witwatersrand mining sector. } \\
\text { The strike was the consequence of a dispute between white mineworkers and the newly appointed mine manager, Mr Bulman, after an } \\
\text { increase in working hours without extra pay and the dismissal of workers who refused to accept the new working hours. The miners wanted } \\
\text { the laws amended. The situation turned violent, the police intervened and called for additional military support. Casualties: } 22 \text { civilians killed; } \\
88 \text { civilians injured; police deaths and injuries: unknown. }\end{array}$} \\
\hline \multirow{4}{*}{$\begin{array}{l}\text { Report of the } \\
\text { Commission } \\
\text { appointed to enquire } \\
\text { into Assaults on } \\
\text { Women }\end{array}$} & Established: Jun 1912 & \multirow{2}{*}{ UG-39/1913 } & \multirow{2}{*}{$\begin{array}{l}\text { Judicial Commission } \\
\text { of Inquiry }\end{array}$} & Melius de Villiers & \multirow{2}{*}{ 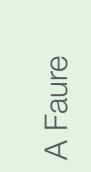 } & \multirow{2}{*}{$\begin{array}{l}\frac{\bar{\Phi}}{\bar{\Xi}} \\
\stackrel{\Psi}{\Psi} \\
\dot{\Sigma}\end{array}$} & \multirow{2}{*}{$\begin{array}{l}\frac{0}{8} \\
8 \\
8 \\
3 \\
\infty\end{array}$} & \multirow{2}{*}{$\begin{array}{ll}\frac{0}{0} & + \\
\frac{\pi}{0} & \frac{0}{3} \\
0 & \frac{0}{0}\end{array}$} & \multirow{2}{*}{ 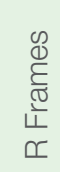 } & \multirow{2}{*}{ 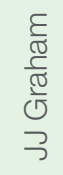 } & \multirow{2}{*}{ 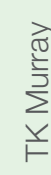 } \\
\hline & Finalised: 1913 & & & $\begin{array}{l}\text { Chief Justice of the } \\
\text { Orange Free State }\end{array}$ & & & & & & & \\
\hline & Terms of reference & \multicolumn{10}{|c|}{$\begin{array}{l}\text { 'To inquire into and report on } \\
\text { (1) the prevalence of sexual assault; } \\
\text { (2) the extent to which such assaults occur; } \\
\text { (3) the causes of the crimes; } \\
\text { (4) prevention of these assaults; } \\
\text { (5) the influence of social and economic factors; and } \\
\text { (6) possible remedies to cope with the assaults.' }\end{array}$} \\
\hline & Context & \multicolumn{10}{|c|}{$\begin{array}{l}\text { According to the commission, sexual assaults rapidly increased during the years } 1901 \text { to } 1912 \text {. The commission had to investigate means } \\
\text { of preventing, suppressing and discouraging sexual attacks. It also turned to a consideration of the role and function of the police vis-à-vis } \\
\text { sexual violence. }\end{array}$} \\
\hline
\end{tabular}




\begin{tabular}{|c|c|c|c|c|c|c|}
\hline Inquiry name & Date & Reference & Type of inquiry & Chairperson & \multicolumn{2}{|c|}{ Commissioner(s) } \\
\hline \multirow{4}{*}{$\begin{array}{l}\text { Report of the Indian } \\
\text { Enquiry Commission }\end{array}$} & Established: 1913 & \multirow{2}{*}{ Cd 7265} & \multirow{2}{*}{ Commission of Inquiry } & \multirow{2}{*}{ William H Solomon } & E Esselen & JS Wylie \\
\hline & Finalised: Mar 1914 & & & & & \\
\hline & Terms of reference & \multicolumn{5}{|c|}{$\begin{array}{l}\text { 'To inquire into and report upon the following: } \\
\text { (1) the disturbance connected to the Indian strike in Natal and the cause and circumstances that led to the strike and disturbances; } \\
\text { (2) the force used to suppress the disturbances and the necessity for the use of such force; } \\
\text { (3) any acts of violence alleged to have been committed against persons imprisoned for acts concerning the strike; and } \\
\text { To make recommendations in respect to any of the above matters.' }\end{array}$} \\
\hline & Context & \multicolumn{5}{|c|}{$\begin{array}{l}\text { The strike was the consequence of Indian leaders' dissatisfaction with the Immigration Regulation Act } 1913 \text { and the restrictions on the } \\
\text { movement of Indians to other provinces. Additionally, they objected to laws referring to the admission and status of Indian women and the } \\
\text { laws prohibiting them from owning unmoveable property and trading licences. The strike was mostly peaceful but turned violent on two } \\
\text { occasions. Casualties: seven civilians killed; } 25 \text { injured. }\end{array}$} \\
\hline
\end{tabular}

\begin{tabular}{|l|l|l|l|l|}
\hline \multirow{4}{*}{$\begin{array}{l}\text { The Public Service } \\
\text { Commission of } \\
\text { Inquiry }\end{array}$} & Established: & \multirow{2}{*}{ UG-54 } & Statutory Commission & TL Graham \\
\cline { 2 - 3 } & Terms of reference & \multirow{2}{*}{ 'To inquire into and report upon matters related to Public Service Divisions.' } & \\
\cline { 2 - 3 } & Context & This was a public service-wide enquiry into conditions of service, including the conditions of service relating to the police organisation. \\
\hline
\end{tabular}

\begin{tabular}{|c|c|c|c|c|c|c|c|}
\hline \multirow{4}{*}{$\begin{array}{l}\text { Report of the Select } \\
\text { Committee on } \\
\text { Police Striking and } \\
\text { Recruiting }\end{array}$} & Established: Jan 1918 & \multirow{2}{*}{ SC-5 } & \multirow{2}{*}{ Select committee } & Andries Stockenström & David Harris & Henwood & HS Grobler \\
\hline & Finalised: Apr 1918 & & & Judge & & Lieutenant colonel & Lieutenant colonel \\
\hline & Terms of reference & \multicolumn{6}{|c|}{$\begin{array}{l}\text { 'To inquire into and report on } \\
\text { (1) methods of recruiting for the South African Police; and } \\
\text { (2) the circumstances leading up to the strike in Cape Town.' }\end{array}$} \\
\hline & Context & \multicolumn{6}{|c|}{$\begin{array}{l}\text { Dissatisfaction among the rank and file culminated in a police strike in the Cape in 1917. Police in Cape Town went on strike to voice their } \\
\text { discontent with differences in the local allowance system. At the time a differential pay structure existed for Transvaal and Cape police and the } \\
\text { police in the Cape regarded the coastal rates of pay as inadequate. Substantial pay rises followed but were of short duration as the post-war } \\
\text { recession forced austerity measures. }\end{array}$} \\
\hline
\end{tabular}




\begin{tabular}{|c|c|c|c|c|c|}
\hline Inquiry name & Date & Reference & Type of inquiry & Chairperson & Commissioner(s) \\
\hline \multirow{4}{*}{\begin{tabular}{|l|} 
Report of the \\
Commissioner \\
appointed to hold \\
an enquiry regarding \\
alleged ill-treatment of \\
natives by members \\
of the police force \\
during the recent \\
native unrest at \\
Johannesburg \\
\end{tabular}} & Established: Apr 1919 & \multirow{2}{*}{ Ann 517/1919 } & \multirow{2}{*}{ Inquiry } & \multirow[t]{2}{*}{ George J Boyes } & \\
\hline & Finalised: May 1919 & & & & \\
\hline & Terms of reference & \multicolumn{4}{|c|}{$\begin{array}{l}\text { 'Enquire into the correctness or otherwise of allegations as to ill-treatment of natives by members of the Police Force during the recent native } \\
\text { unrest at Johannesburg' }\end{array}$} \\
\hline & Context & \multicolumn{4}{|c|}{$\begin{array}{l}\text { Demonstrations against pass laws and the administration thereof took place in Johannesburg. Various complaints relating to police conduct } \\
\text { were received. It was alleged that the police harmed demonstrators at the point of arrest and during their detention. }\end{array}$} \\
\hline \multirow{4}{*}{\begin{tabular}{|l|} 
Report of the \\
commissioners \\
appointed to enquire \\
into the causes of, \\
and occurrences at, \\
the native disturbance \\
at Port Elizabeth on \\
23 October 1920 , and \\
the general economic \\
conditions as they \\
affect the native and \\
coloured population \\
\end{tabular}} & Established: 1920 & \multirow[b]{2}{*}{$\mathrm{A} 4 / 5$} & \multirow[b]{2}{*}{ Commission of Inquiry } & \multirow[t]{2}{*}{ CW Schweizer } & A Abdulrahman \\
\hline & Finalised: 1921 & & & & $\begin{array}{l}\text { President of African People's } \\
\text { Organisation (APO) }\end{array}$ \\
\hline & Terms of reference & \multicolumn{4}{|c|}{$\begin{array}{l}\text { 'Inquire into, and report upon: } \\
\text { (1) The causes of, and the occurrences at, the Native disturbance at Port Elizabeth. } \\
\text { To inquire into the general economic conditions of the native and coloured population.' }\end{array}$} \\
\hline & Context & \multicolumn{4}{|c|}{$\begin{array}{l}\text { Mr Masabalala, the president of a workers' union, urged members to strike for higher wages. He was arrested and the police refused to } \\
\text { release him on bail. A crowd gathered to demand the release of their leader. The police used force, killing and wounding many people. } \\
\text { Casualties: } 24 \text { persons killed and } 50 \text { treated for wounds. }\end{array}$} \\
\hline \multirow{4}{*}{$\begin{array}{l}\text { Interim and Final } \\
\text { Reports of the Native } \\
\text { Affairs Commission } \\
\text { and telegram from } \\
\text { Commissioner, } \\
\text { South African Police, } \\
\text { relative to 'Israelites' } \\
\text { at Bulhoek and } \\
\text { Occurrences in } \\
\text { May } 1921\end{array}$} & Established: 1921 & \multirow{2}{*}{ A 4-'21 } & & \multirow{2}{*}{ Alex W Roberts } & \\
\hline & Finalised: 1921 & & Commission & & \\
\hline & Terms of reference & \multicolumn{4}{|c|}{$\begin{array}{l}\text { 'Discuss and report upon the attitude of certain Africans belonging to the religious sect called the "Israelites" who have taken up their abode } \\
\text { in the Bulhoek sub-location.' }\end{array}$} \\
\hline & Context & \multicolumn{4}{|c|}{$\begin{array}{l}\text { The Israelites religious sect held annual Passover services at Ntabilanga commonage land, after which the members would disperse. After } \\
\text { the April } 1920 \text { service, the members failed to disperse. The police issued summons, which were ignored. The commission investigated the } \\
\text { events and recommended that a portion of the site be used for religious purposes. The government accepted the recommendations but the } \\
\text { Israelites rejected the recommendations. On recommendation of the commission the police were despatched on } 24 \text { May } 1921 \text { to evict the } \\
\text { Israelites. They resisted and the police used lethal force. The casualties were as follows: } 163 \text { dead, } 129 \text { wounded and } 95 \text { prisoners. After } \\
\text { finding and arresting Enoch Mgijma, their prophet, all resistance ended. }\end{array}$} \\
\hline
\end{tabular}




\begin{tabular}{|c|c|c|c|c|c|c|}
\hline Inquiry name & Date & Reference & Type of inquiry & Chairperson & \multicolumn{2}{|c|}{ Commissioner(s) } \\
\hline \multirow{4}{*}{$\begin{array}{l}\text { Report of the } \\
\text { Commission } \\
\text { appointed to enquire } \\
\text { into the Rebellion of } \\
\text { the Bondelzwarts }\end{array}$} & Established: Jul 1922 & \multirow{2}{*}{ UG-16/1923 } & \multirow{2}{*}{ Commission of Inquiry } & Alex W Roberts & CT Loram & LAS Lemmer \\
\hline & Finalised: Mar 1923 & & & & & \\
\hline & Terms of reference & \multicolumn{5}{|c|}{$\begin{array}{l}\text { 'To inquire into and report upon the following: } \\
\text { (1) 'The causes of the Bondelzwarts Rebellion. } \\
\text { (2) Whether and to what extent the Union side of the Orange River influenced the rebellion. } \\
\text { (3) Recommendations for remedial action concerning (1) and (2).' }\end{array}$} \\
\hline & Context & \multicolumn{5}{|c|}{$\begin{array}{l}\text { A rebellion among the nomadic Bondelzwarts people followed after an increase in taxes. Police responded with lethal force. Casualties of the } \\
\text { rebellion were at least } 62 \text { killed and an unknown number of injuries. }\end{array}$} \\
\hline
\end{tabular}

\begin{tabular}{|c|c|c|c|c|c|}
\hline \multirow{4}{*}{$\begin{array}{l}\text { Commission of } \\
\text { Inquiry into } \\
\text { Native riots at } \\
\text { Bloemfontein }\end{array}$} & Established: Jun 1925 & \multirow{2}{*}{ Ann No. 1553} & \multirow{2}{*}{ Commission of Inquiry } & \multirow[t]{2}{*}{ AGE Pienaar } & \multirow[t]{2}{*}{ SA McCormick } \\
\hline & Finalised: Aug 1925 & & & & \\
\hline & Terms of reference & \multicolumn{4}{|c|}{$\begin{array}{l}\text { (1) 'The nature of the riot and the force used to quell it; } \\
\text { (2) The causes giving rise to unrest and the circumstances leading up to the riot; and } \\
\text { (3) The nature of the establishment and control of the native location at Bloemfontein.' }\end{array}$} \\
\hline & Context & \multicolumn{4}{|c|}{$\begin{array}{l}\text { The riot followed the introduction of restrictions on the use of alcohol. African women then gathered and consumed alcohol in public in } \\
\text { defiance of the restrictions. Scuffles broke out and the police shot dead a civilian. A strike ensued and the demonstration gained momentum. } \\
\text { Casualties: five killed and } 24 \text { wounded, } 19 \text { police members wounded. }\end{array}$} \\
\hline
\end{tabular}

\begin{tabular}{|c|c|c|c|c|c|c|}
\hline \multirow{4}{*}{$\begin{array}{l}\text { Report of the } \\
\text { Commission of } \\
\text { Enquiry into the } \\
\text { organisation of the } \\
\text { South African Police } \\
\text { Force, Established } \\
\text { under Act No. } 14 \\
\text { of } 1912\end{array}$} & Established: Aug 1925 & \multirow{2}{*}{ UG-23/1926 } & \multirow{2}{*}{$\begin{array}{l}\text { Judicial Commission } \\
\text { of Inquiry }\end{array}$} & Charles te Water & James Young & Charles Pearce \\
\hline & Finalised: Mar 1926 & & & Advocate & Magistrate & \\
\hline & Terms of reference & \multicolumn{5}{|c|}{$\begin{array}{l}\text { 'Inquire and report upon matters related to the South African Police Force's: } \\
\text { (1) Headquarters; } \\
\text { (2) Criminal Investigation or Detective Department; } \\
\text { (3) The Executive Force; } \\
\text { (4) General inquiries.' }\end{array}$} \\
\hline & Context & \multicolumn{5}{|c|}{$\begin{array}{l}\text { In the post-war recession, austerity measures led to a freezing of posts and promotions, a cut in local allowances, and a reduction in } \\
\text { salaries. Police morale was said to be low and the public image of the police left much to be desired. The commission inquired into various } \\
\text { administrative matters relating to the police as an establishment. }\end{array}$} \\
\hline
\end{tabular}




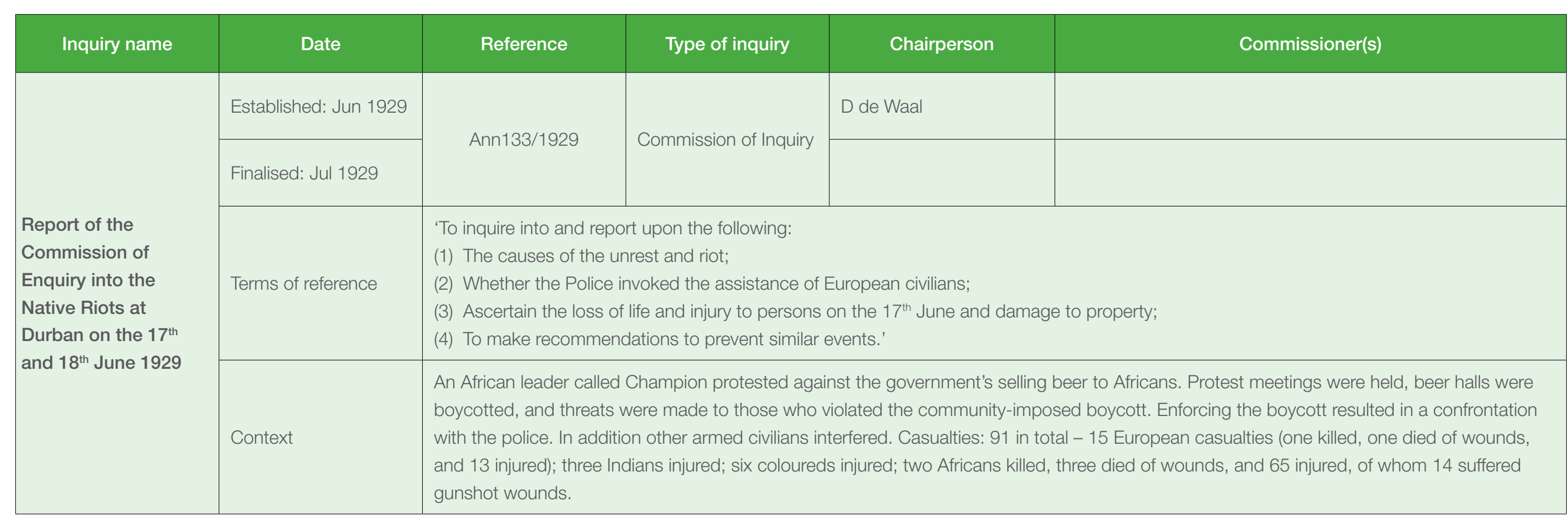

\begin{tabular}{|c|c|c|c|c|c|}
\hline \multirow{4}{*}{$\begin{array}{l}\text { Interim and Final } \\
\text { Reports of the } \\
\text { Commission of } \\
\text { Inquiry to inquire } \\
\text { into certain matters } \\
\text { concerning the South } \\
\text { African Police and } \\
\text { the South African } \\
\text { Railways and } \\
\text { Harbours Police }\end{array}$} & Established: Sept 1936 & \multirow{2}{*}{ UG-50/1937 } & \multirow{2}{*}{ Commission of Inquiry } & C Lansdown & CW de Villiers \\
\hline & Finalised: 1937 & & & & \\
\hline & Terms of reference & \multicolumn{4}{|c|}{$\begin{array}{l}\text { 'To inquire into the following matters regarding the South African Police: } \\
\text { (1) Pay rates, promotion, recruitment and training; } \\
\text { (2) Laws and prevention of corruption thereof; } \\
\text { (3) Allegations concerning the conduct of police during crime investigation; } \\
\text { (4) Police and non-European relations; and } \\
\text { (5) The relations between the police and public.' }\end{array}$} \\
\hline & Context & \multicolumn{4}{|c|}{$\begin{array}{l}\text { The appointment of the commission was prompted by allegations of extensive police corruption on the Witwatersrand. During this period } \\
\text { various administrative issues that had long confronted the organisation were still to be resolved. The Lansdown Commission inquired about } \\
\text { several challenges that confronted the organisation, from general conditions of service to allegations of corruption in the administration of } \\
\text { gold, liquor and diamond laws, since amalgamation in 1913. Issues probed included conditions of service; investigative skills; the nature of } \\
\text { community-policing relationships; and allegations of police brutality. The committee also reported extensively on racial stratification within the } \\
\text { police organisation. }\end{array}$} \\
\hline
\end{tabular}




\begin{tabular}{|c|c|c|c|c|c|}
\hline Inquiry name & Date & Reference & Type of inquiry & Chairperson & Commissioner(s) \\
\hline \multirow{4}{*}{$\begin{array}{l}\text { Report of the } \\
\text { Commission into } \\
\text { the Riots and } \\
\text { Disturbances at } \\
\text { Vereeniging on 18-19 } \\
\text { Sept } 1937\end{array}$} & Established: & \multirow{2}{*}{ UG-31 } & \multirow{2}{*}{ Commission of Inquiry } & DL Smit & \\
\hline & Finalised: 1938 & & & & \\
\hline & Terms of reference & \multicolumn{4}{|c|}{$\begin{array}{l}\text { (1) 'To inquire into and report upon all matters leading to and culminating in certain riots and disturbances which occurred in the Native } \\
\text { location at Vereeniging on } 18 \text { \& } 19 \text { September 1937; and } \\
\text { (2) To make recommendations to address the circumstances.' }\end{array}$} \\
\hline & Context & \multicolumn{4}{|c|}{$\begin{array}{l}\text { Liquor raids - particularly in African areas of settlement - formed a routine part of police duties. On } 18 \text { September } 1937 \text {, the police raided } \\
\text { the location In Vereeniging for illegal liquor. Large numbers of residents resisted the raids. On Sunday, } 19 \text { September, the police arranged a } \\
\text { second raid and asked for reinforcements. An estimated crowd of some } 700 \text { to } 2000 \text { gathered. The police opened fire. Two police constables } \\
\text { were killed; four seriously injured; the number of police and community members with minor injuries not known. The commission found that } \\
\text { the police exceeded their statutory powers. The incident was under inquiry in criminal proceedings that ran concurrently with the commission. }\end{array}$} \\
\hline
\end{tabular}

\begin{tabular}{|c|c|c|c|c|c|c|}
\hline \multirow{4}{*}{$\begin{array}{l}\text { Report of the } \\
\text { Commission } \\
\text { appointed to enquire } \\
\text { into the riots which } \\
\text { took place in } \\
\text { Johannesburg on } \\
31 \text { January } 1941 \text {, and } \\
1 \text { February } 1941\end{array}$} & Established: Feb 1941 & \multirow{2}{*}{$8 / 1941$} & \multirow{2}{*}{$\begin{array}{l}\text { Judicial Commission } \\
\text { of Inquiry }\end{array}$} & Sydney H Elliot & Menzies Murray & Petrus I Hoogenhout \\
\hline & Finalised: Mar 1941 & & & Magistrate & Advocate & Colonel \\
\hline & Terms of reference & \multicolumn{5}{|c|}{$\begin{array}{l}\text { 'To inquire into: } \\
\text { (1) the attacks at Johannesburg; } \\
\text { (2) the causes of these attacks; } \\
\text { (3) circumstances in which these attacks took place; and } \\
\text { (4) injuries to persons and the damage to property.' }\end{array}$} \\
\hline & Context & \multicolumn{5}{|c|}{$\begin{array}{l}\text { On } 31 \text { January } 1941 \text { violent clashes between off-duty soldiers and members of the Ossewabrandwag occurred. The police used considerable } \\
\text { violence against both civilians and soldiers to end the hostile situation. The civilians decided to join forces with the police, after which the } \\
\text { police tactfully withdrew. The soldiers rioted the following day (damaging buildings and property) and the police met the rioters with force. }\end{array}$} \\
\hline
\end{tabular}

\begin{tabular}{|c|c|c|c|c|c|c|c|}
\hline \multirow{4}{*}{$\begin{array}{l}\text { Judicial Commission } \\
\text { of Enquiry - Pretoria } \\
\text { municipal riot of } 28 \\
\text { December } 1942 \\
\text { Report }\end{array}$} & Established: Dec 1942 & \multirow{2}{*}{ Ann $\mathrm{H} / 1943$} & \multirow{2}{*}{$\begin{array}{l}\text { Judicial Commission } \\
\text { of Inquiry }\end{array}$} & JM Murray & CE Morris & WT Welsh & AS Welsh \\
\hline & Finalised: 1943 & & & Judge & & & $\begin{array}{l}\text { Former Attorney } \\
\text { General - Transvaal }\end{array}$ \\
\hline & Terms of reference & \multicolumn{6}{|c|}{$\begin{array}{l}\text { 'Enquire into and report upon all matters leading up to and culminating in the incidents, and to make any recommendations which might } \\
\text { seem correct in the circumstances.' }\end{array}$} \\
\hline & Context & \multicolumn{6}{|c|}{$\begin{array}{l}\text { A wage dispute resulted in a riot that then developed into a confrontation between African labourers and the police. The military also } \\
\text { intervened and a shootout showdown ensued. Casualties: } 16 \text { Africans and one European killed; } 65 \text { injured. }\end{array}$} \\
\hline
\end{tabular}




\begin{tabular}{|c|c|c|c|c|c|c|c|}
\hline Inquiry name & Date & Reference & Type of inquiry & Chairperson & \multicolumn{3}{|c|}{ Commissioner(s) } \\
\hline \multirow{4}{*}{$\begin{array}{l}\text { Report of the } \\
\text { Commission to } \\
\text { enquire into the } \\
\text { disturbances of } \\
\text { the 30th August, } \\
\text { 1947, at the Moroka } \\
\text { Emergency Camp, } \\
\text { Johannesburg }\end{array}$} & Established: Sept 1947 & & \multirow{2}{*}{ Commission of Inquiry } & HA Fagan & AL Barrett & AE Welsh & AE von Maltitz \\
\hline & Finalised: 1948 & & & & & & \\
\hline & Terms of reference & \multicolumn{6}{|c|}{$\begin{array}{l}\text { (1) 'To inquire into and report upon the disturbances at the Moroka Emergency Camp; } \\
\text { (2) the causes thereof; and } \\
\text { (3) to make recommendations.' }\end{array}$} \\
\hline & Context & \multicolumn{6}{|c|}{$\begin{array}{l}\text { Illegal squatters were relocated to the temporary Moroka emergency camp near Kliptown in Soweto. The town council decided to issue trade } \\
\text { licences for stalls operating in the camp. All unlicensed traders were removed from the camp. Only three of the } 26 \text { successful applicants were } \\
\text { Moroka residents. Frustrations resulting from alleged bias in the allocation of such licences as well as high rental charges led to an attack on } \\
\text { the newly opened shops. Six police members intervened, three of whom were killed. }\end{array}$} \\
\hline
\end{tabular}

\begin{tabular}{|c|c|c|c|c|c|c|c|}
\hline \multirow{4}{*}{$\begin{array}{l}\text { Report of } \\
\text { Commission of } \\
\text { Enquiry into Riots in } \\
\text { Durban }\end{array}$} & Established: Jan 1949 & \multirow{2}{*}{ UG-36/1949 } & \multirow{2}{*}{ Commission of Inquiry } & \multirow[t]{2}{*}{ F van der Heever } & R Masson & \multirow[t]{2}{*}{ W Schulz } & \multirow[t]{2}{*}{ BC van der Merwe } \\
\hline & Finalised: Apr 1949 & & & & & & \\
\hline & Terms of reference & \multicolumn{6}{|c|}{$\begin{array}{l}\text { 'To inquire into and report upon: } \\
\text { (1) The events leading to, and the causes of, the Durban and vicinity riots; and } \\
\text { (2) The possibility of strained relationships preceding the riot; and the cause of the strained relations.' }\end{array}$} \\
\hline & Context & \multicolumn{6}{|c|}{$\begin{array}{l}\text { A tussle between a shop owner and shop assistant led to a wider outbreak of conflict between Indians and Africans in Durban. The police } \\
\text { used coercive and lethal force but failed to prevent and contain the riot. Casualties: } 142 \text { deaths and } 1087 \text { injuries ( } 58 \text { of the injured died). }\end{array}$} \\
\hline
\end{tabular}

\begin{tabular}{|c|c|c|c|c|c|c|}
\hline \multirow{4}{*}{$\begin{array}{l}\text { Report of the } \\
\text { Commission } \\
\text { appointed to } \\
\text { enquire into Acts of } \\
\text { Violence Committed } \\
\text { by Natives at } \\
\text { Krugersdorp, } \\
\text { Newlands, } \\
\text { Randfontein, and } \\
\text { Newclare }\end{array}$} & Established: Nov 1949 & \multirow{2}{*}{ UG-47 } & \multirow{2}{*}{ Commission of Inquiry } & J de V Louw & Rudolph Wronsky & CW Prinsloo \\
\hline & Finalised: 1950 & & & & & \\
\hline & Terms of reference & \multicolumn{5}{|c|}{$\begin{array}{l}\text { 'To inquire into and report upon: } \\
\text { (1) The events leading to violence and riots; } \\
\text { (2) The relationship (if any) between the occurrences; and } \\
\text { (3) The incitement of the occurrences.' }\end{array}$} \\
\hline & Context & \multicolumn{5}{|c|}{$\begin{array}{l}\text { The riots in the different localities were unrelated, resulting from separate causes, such as increased tram fares in Newlands; more frequent } \\
\text { liquor raids in Krugersdorp and Randfontein; and the arrest of an African person on liquor-related charges in Newclare. The police intervened } \\
\text { to disperse the crowds. The casualties: six Africans killed; } 17 \text { Africans injured; and } 62 \text { police members injured. }\end{array}$} \\
\hline
\end{tabular}




\begin{tabular}{|c|c|c|c|c|c|}
\hline Inquiry name & Date & Reference & Type of inquiry & Chairperson & Commissioner(s) \\
\hline \multirow{4}{*}{$\begin{array}{l}\text { Report of the } \\
\text { Commission } \\
\text { of Enquiry into } \\
\text { Allegations against } \\
\text { Members of the } \\
\text { South African Police }\end{array}$} & Established: Nov 1949 & \multirow{2}{*}{ UG-48/1950 } & \multirow{2}{*}{ Statutory Inquiry } & $\mathrm{OH}$ Hoexter & \\
\hline & Finalised: Mar 1950 & & & & \\
\hline & Terms of reference & \multicolumn{4}{|c|}{$\begin{array}{l}\text { 'To inquire into and report upon: } \\
\text { (1) bribery and negligence committed by police officers; } \\
\text { (2) any alleged delay, irregularity or malpractice not falling under which may be brought to the notice of the commissioner; } \\
\text { (3) any alleged delay, irregularity or malpractice linked with liquor trafficking. } \\
\text { Any matter directly or indirectly connected to (1), (2), or (3) necessary to inquire into; and persons against whom action should be taken, } \\
\text { resulting from the findings of the commission in terms of its reference.' }\end{array}$} \\
\hline & Context & \multicolumn{4}{|c|}{$\begin{array}{l}\text { Lt Duncker raided a room on } 16 \text { January } 1948 \text { and found excessive amounts of illegal liquor. The tenant, an elderly Chinese man, produced } \\
\text { a police permit for the liquor. It soon became evident that the Chinese man was under the protection of a certain Colonel Talken. After more } \\
\text { investigation, it became clear that police officers accepted bribes to cover up illegal activities, such as liquor trafficking and abortions in the } \\
\text { Johannesburg area. }\end{array}$} \\
\hline
\end{tabular}

\begin{tabular}{|c|c|c|c|c|c|c|}
\hline \multirow{4}{*}{$\begin{array}{l}\text { Report of the } \\
\text { Commission of } \\
\text { Enquiry into the } \\
\text { Disturbances in the } \\
\text { Witzieshoek Native } \\
\text { Reserve }\end{array}$} & Established: Oct 1950 & \multirow{2}{*}{ UG 26/1951 } & \multirow{2}{*}{ Commission of Inquiry } & A Eyles & GEN Ross & CJ van Heerder \\
\hline & Finalised: Feb 1951 & & & & & \\
\hline & Terms of reference & \multicolumn{5}{|c|}{$\begin{array}{l}\text { 'Enquire and report on: } \\
\text { (1) The causes of the recent unrest and disturbances in the Witzieshoek Native Reserve, District Harrismith, and the steps which should be } \\
\text { taken to put an end to the said unrest and disturbances, and } \\
\text { (2) Whether the Reserve aforesaid is overpopulated and overstocked and, if so, what steps should be taken to remedy this.' }\end{array}$} \\
\hline & Context & \multicolumn{5}{|c|}{$\begin{array}{l}\text { A betterment programme was established and included fencing off land, exercising grazing control and stock culling. The Witzieshoek } \\
\text { inhabitants, however, were of two minds concerning the betterment programme. After several confrontations a riot ensued. The commission } \\
\text { investigated and during the first round of hearings further conflict erupted, which resulted in casualties and injuries. Two police members and } \\
14 \text { Africans were killed. }\end{array}$} \\
\hline
\end{tabular}




\begin{tabular}{|c|c|c|c|c|c|c|c|c|}
\hline Inquiry name & Date & Reference & Type of inquiry & Chairperson & \multicolumn{4}{|c|}{ Commissioner(s) } \\
\hline \multirow{4}{*}{$\begin{array}{l}\text { Report of the } \\
\text { Departmental } \\
\text { Committee of enquiry } \\
\text { on Pensions (South } \\
\text { African Police Force) }\end{array}$} & Established: & \multirow[b]{2}{*}{ UG-59/1954 } & \multirow[b]{2}{*}{$\begin{array}{l}\text { Departmental } \\
\text { committee }\end{array}$} & JH Basson & JP de Villiers & $\begin{array}{l}\text { Brig. MP } \\
\text { Coetzee }\end{array}$ & $\begin{array}{l}\text { Col HJ } \\
\text { du Plooy }\end{array}$ & $\begin{array}{l}\text { Col JM } \\
\text { Keevy }\end{array}$ \\
\hline & Finalised: Oct 1953 & & & $\begin{array}{l}\text { Deputy Commissioner of } \\
\text { Pensions }\end{array}$ & $\begin{array}{l}\text { Under- } \\
\text { secretary for } \\
\text { Defence }\end{array}$ & $\begin{array}{l}\text { Assistant } \\
\text { Commissioner } \\
\text { SAP }\end{array}$ & $\begin{array}{l}\text { SAP head- } \\
\text { quarters }\end{array}$ & $\begin{array}{l}\text { Quarter- } \\
\text { master } \\
\text { SAP }\end{array}$ \\
\hline & Terms of reference & \multicolumn{7}{|c|}{$\begin{array}{l}\text { 'Inquire into and report upon: } \\
\text { (1) The desirability and possibility of instituting a separate pension fund; } \\
\text { (2) Improvement in general of annuities and gratuities; and } \\
\text { (3) Introducing a widow's fund.' }\end{array}$} \\
\hline & Context & \multicolumn{7}{|c|}{$\begin{array}{l}\text { There could be no immediate improvement in the overall conditions of service. As compensation, improvement in pension benefits was } \\
\text { deemed both reasonable and feasible. }\end{array}$} \\
\hline
\end{tabular}

\begin{tabular}{|c|c|c|c|c|c|}
\hline \multirow{4}{*}{$\begin{array}{l}\text { Report of the } \\
\text { Commission } \\
\text { appointed by the } \\
\text { City Council of } \\
\text { Johannesburg } \\
\text { to enquire into } \\
\text { the causes and } \\
\text { circumstances of } \\
\text { the riots which took } \\
\text { place in the vicinity } \\
\text { of the Dube Hostel in } \\
\text { the South-Western } \\
\text { Native Township over } \\
\text { the weekend } 14 / 15 \\
\text { September } 1957\end{array}$} & Established: Oct 1957 & \multirow{2}{*}{$\begin{array}{l}\text { 1/1958 } \\
\text { G685 VJ3 }\end{array}$} & \multirow{2}{*}{$\begin{array}{l}\text { Judicial Commission } \\
\text { of Inquiry }\end{array}$} & Albert v S Centlivres & \\
\hline & Finalised: Apr 1958 & & & $\begin{array}{l}\text { Chief Justice of South } \\
\text { Africa }\end{array}$ & \\
\hline & Terms of reference & \multicolumn{4}{|c|}{$\begin{array}{l}\text { 'To inquire into: } \\
\text { (1) The immediate causes of the riot which took place in the South-Western Native areas during the weekend of } 14^{\text {th }} \text { and } 15^{\text {th }} \text { September, } \\
1957 \text {; } \\
\text { (2) The root causes of the conditions of unrest in the South-Western Native areas which have given rise to the riots; } \\
\text { (3) What remedial measures may be necessary to and advisable to avoid similar happenings in the future.' }\end{array}$} \\
\hline & Context & \multicolumn{4}{|c|}{$\begin{array}{l}\text { The commission was established to investigate riots in Soweto. It was alleged that tsotsis (of Basotho origin) frequently assaulted and } \\
\text { robbed Zulu residents. After an ostensibly drunken quarrel, two inmates of the Meadowlands hostel were shot. This incident fuelled animosity } \\
\text { between the Dube and Meadowlands hostels. Further events led to more fighting and deaths. Armed Zulu mourners en route to a funeral were } \\
\text { dispersed by the police. }\end{array}$} \\
\hline
\end{tabular}




\begin{tabular}{|c|c|c|c|c|c|}
\hline Inquiry name & Date & Reference & Type of inquiry & Chairperson & Commissioner(s) \\
\hline \multirow{4}{*}{$\begin{array}{l}\text { Report of the } \\
\text { Commission } \\
\text { Appointed to } \\
\text { Investigate and } \\
\text { Report on the } \\
\text { Occurrences in } \\
\text { the Districts of } \\
\text { Vereeniging, namely } \\
\text { at Sharpeville } \\
\text { Location, and Evaton, } \\
\text { and Vanderbijlpark, } \\
\text { Province of the } \\
\text { Transvaal, on } 21^{\text {st }} \\
\text { March, } 1960\end{array}$} & Established: April 1960 & & \multirow{2}{*}{$\begin{array}{l}\text { Judicial Commission } \\
\text { of Inquiry }\end{array}$} & PJ Wessels & \\
\hline & Finalised: 1960 & & & Judge & \\
\hline & Terms of reference & \multicolumn{4}{|c|}{$\begin{array}{l}\text { 'To investigate and report on the occurrences in the Districts Vereeniging (namely, at Sharpeville Location and Evaton) and Vanderbijpark, } \\
\text { Province of the Transvaal, on } 21^{\text {st }} \text { March 1960.' }\end{array}$} \\
\hline & Context & \multicolumn{4}{|c|}{$\begin{array}{l}\text { Countrywide demonstrations against pass laws were planned for } 1960 \text { under the leadership of the Pan Africanist Congress (PAC). } \\
\text { Townships in the Vaal Triangle formed the centre of an 'insurrectionary rebellion'. On } 21 \text { March } 1960 \text { a crowd of about } 5000 \text { to } 7000 \text { people } \\
\text { congregated at the police station in Sharpeville. Between } 300 \text { and } 400 \text { armed police officers were deployed at the station. Live ammunition } \\
\text { was used by the police and resulted in } 69 \text { deaths and } 180 \text { injuries. Many of those shot were shot in the back. The Sharpeville massacre } \\
\text { provoked widespread international condemnation. The commission presented detailed accounts of the events as they unfolded at the different } \\
\text { locations. The occurrences of } 21 \text { March do not stand in isolation and occurred elsewhere (see Diemont Commission). }\end{array}$} \\
\hline
\end{tabular}

\begin{tabular}{|c|c|c|c|c|}
\hline \multirow{4}{*}{$\begin{array}{l}\text { Report of the } \\
\text { Commission of } \\
\text { enquiry into the } \\
\text { events in Langa } \\
\text { Location, district of } \\
\text { Wynberg, Cape of } \\
\text { Good Hope, on } 21^{\text {st }} \\
\text { March } 1960\end{array}$} & Established: Apr 1960 & \multirow{2}{*}{ Ann $126 / 61$} & \multirow{2}{*}{$\begin{array}{l}\text { Judicial Commission } \\
\text { of Inquiry }\end{array}$} & Marius Diemont \\
\hline & Finalised: Jul 1960 & & & Judge \\
\hline & Terms of reference & 'To inquire int & t upon the events in $L$ & ya Location, District of Wynberg, Cape of Good Hope, on 21 March 1960.' \\
\hline & Context & $\begin{array}{l}\text { To find the ca } \\
\text { abolition of th } \\
\text { force to dispe }\end{array}$ & $\begin{array}{l}\text { iot was not part of the } \\
\text { s as well as a minimum } \\
\text { wd. }\end{array}$ & $\begin{array}{l}\text { mmission's reference. Groups of people met to discuss their demands relating to the } \\
\text { age. Police arrived to disperse the crowd. After a three-minute warning, the police used }\end{array}$ \\
\hline
\end{tabular}




\begin{tabular}{|c|c|c|c|c|c|}
\hline Inquiry name & Date & Reference & Type of inquiry & Chairperson & Commissioner(s) \\
\hline \multirow{4}{*}{$\begin{array}{l}\text { Interim and Final } \\
\text { Report of the } \\
\text { Commission to } \\
\text { inquire into the } \\
\text { events at Paarl and } \\
\text { the causes which } \\
\text { gave rise thereto }\end{array}$} & Established: Nov 1962 & \multirow{2}{*}{ RP-51/1963 } & \multirow{2}{*}{$\begin{array}{l}\text { Judicial Commission } \\
\text { of Inquiry }\end{array}$} & JH Snyman & \\
\hline & Finalised: Jun 1963 & & & Judge & \\
\hline & Terms of reference & \multicolumn{4}{|c|}{$\begin{array}{l}\text { 'To inquire into and report upon: } \\
\text { (1) the events on the } 20^{\text {th }} \text { to } 22^{\text {nd }} \text { November, } 1962 \text {, at Paarl; and } \\
\text { (2) the causes which gave rise thereto.' }\end{array}$} \\
\hline & Context & \multicolumn{4}{|c|}{$\begin{array}{l}\text { In the latter part of } 1962 \text { a branch of POQO (the armed wing of PAC) was actively recruiting members in the Paarl. Much secrecy surrounded } \\
\text { these efforts. An acrimonious relationship between municipal 'Bantu' officials and POQO provided fuel for conflict. On } 14 \text { April } 1962 \text { a rumour } \\
\text { surfaced that POQO was planning to burn down the houses of municipal police. Skirmishes ensued that left two SAP members and one } \\
\text { municipal official dead. Those suspected of being POQO members were then targeted by municipal police. The SAP increased night patrols } \\
\text { and conducted various raids. POQO staged a counter-attack. At } 2 \text { am on the morning of } 22 \text { November } 200-250 \text { armed men took to the } \\
\text { streets. The police station was attacked. The police shot at the crowd. The crowd broke into smaller groups and a number of houses in Loop } \\
\text { Street were attacked and two persons killed. The commission found the 'action of the police fully justified'. In total five citizens were killed and } \\
14 \text { wounded. }\end{array}$} \\
\hline \multirow{4}{*}{$\begin{array}{l}\text { Interim Report of the } \\
\text { Commission of Inquiry } \\
\text { into matters relating } \\
\text { to the Security of the } \\
\text { State }\end{array}$} & Established: Sept 1969 & \multirow{2}{*}{ RP-17/1970 } & \multirow{2}{*}{$\begin{array}{l}\text { Judicial Commission } \\
\text { of Inquiry }\end{array}$} & HJ Potgieter & \\
\hline & Finalised: Nov 1969 & & & Judge & \\
\hline & Terms of reference & \multicolumn{4}{|c|}{ 'To urgently inquire into the allegations of false year-end estimates for the Bureau for State Security.' } \\
\hline & Context & \multicolumn{4}{|c|}{$\begin{array}{l}\text { The commission attended to allegations about the bureau's expenditure for the financial year. The allegation was that its expenditure was } \\
\text { R50 million; however, the commission found that it was R1 } 350000 .\end{array}$} \\
\hline \multirow{4}{*}{$\begin{array}{l}\text { Final Report of the } \\
\text { Commission of Inquiry } \\
\text { into matters relating } \\
\text { to the Security of the } \\
\text { State }\end{array}$} & Established: Sept 1969 & \multirow{2}{*}{ RP-102/1971 } & \multirow{2}{*}{$\begin{array}{l}\text { Judicial Commission } \\
\text { of Inquiry }\end{array}$} & HJ Potgieter & \\
\hline & Finalised: Aug 1971 & & & Judge & \\
\hline & Terms of reference & \multicolumn{4}{|c|}{$\begin{array}{l}\text { 'To inquire into and report upon the following matters related to the security of the state: } \\
\text { (1) efficiency and functionality of concerned departments; } \\
\text { (2) threats to efficient functionality; } \\
\text { (3) further aspects concerning the security structure of the state; } \\
\text { (4) amending legislation; and } \\
\text { (5) releasing the report to the public.' }\end{array}$} \\
\hline & Context & \multicolumn{4}{|c|}{$\begin{array}{l}\text { In the political context of the time the government was concerned about 'state security'. The commission investigated and compared the } \\
\text { security and intelligence bodies to the intelligence agencies of other countries such as New Zealand to determine the competency of the } \\
\text { South African intelligence sector. }\end{array}$} \\
\hline
\end{tabular}




\begin{tabular}{|c|c|c|c|c|c|}
\hline Inquiry name & Date & Reference & Type of inquiry & Chairperson & Commissioner(s) \\
\hline \multirow{4}{*}{$\begin{array}{l}\text { Report of the } \\
\text { Commission of } \\
\text { Inquiry into certain } \\
\text { matters relating to the } \\
\text { University of the North }\end{array}$} & Established: Nov 1974 & & \multirow{2}{*}{$\begin{array}{l}\text { Judicial Commission } \\
\text { of Inquiry }\end{array}$} & JH Snyman & \\
\hline & Finalised: Jun 1975 & & & $\begin{array}{l}\text { Judge of the Supreme } \\
\text { Court }\end{array}$ & \\
\hline & Terms of reference & \multicolumn{4}{|c|}{$\begin{array}{l}\text { 'To inquire and report on: } \\
\text { (1) The events on } 25 \text { September } 1974 \text { on the campus of the University of the North with the view to determining the cause that gave rise } \\
\text { thereto and the part played therein by the University Management, the Student Representative Council and any other organization of } \\
\text { either the students or the lecturers with specific attention to - } \\
\text { (a) The relationship on the campus between the Black and White academic staff as well as between the Black academic staff and the } \\
\text { students; and } \\
\text { (b) Related matters concerning the present and future management of the University, including possible interference therein by the Black } \\
\text { Academic Staff Association; } \\
\text { (2) Any related matter that comes to the notice of the Commission and which in its view calls for inquiry. } \\
\text { To make recommendations in view of the findings, which the Commission deems necessary.' }\end{array}$} \\
\hline & Context & \multicolumn{4}{|c|}{$\begin{array}{l}\text { Nationwide festivities were planned to celebrate the successes of Frelimo (the Mozambican liberation movement that fought for the } \\
\text { independence of the Portuguese overseas province of Mozambique). The South African government decided to ban the festivities across the } \\
\text { country. Students of the University of the North ignored the ban. After a few incidents the police were called to monitor the situation caused by } \\
\text { what the commission called an 'anti-white feeling'. }\end{array}$} \\
\hline
\end{tabular}

\begin{tabular}{|c|c|c|c|c|c|}
\hline \multirow{4}{*}{$\begin{array}{l}\text { Report of the } \\
\text { Commission of } \\
\text { Inquiry into the } \\
\text { Riots at Soweto and } \\
\text { elsewhere from the } 16 \\
\text { of June } 1976 \text { to } \\
28 \text { of February } 1977\end{array}$} & Established: July 1976 & \multirow{2}{*}{ RP-55/1980 } & \multirow{2}{*}{$\begin{array}{l}\text { Judicial Commission } \\
\text { of Inquiry }\end{array}$} & Petrus 1 & \\
\hline & Finalised: 1980 & & & Judge & \\
\hline & Terms of reference & \multicolumn{4}{|c|}{ 'To inquire into and report on the riots, and the causes which gave rise thereto.' } \\
\hline & Context & \multicolumn{4}{|c|}{$\begin{array}{l}\text { The Soweto uprising of } 1976 \text { was fuelled by a wide range of factors. However, the decision to enforce the use of Afrikaans as a medium of } \\
\text { instruction at schools provided a mobilising trigger for social resistance. Attempts on the part of teachers, school boards, concerned parents } \\
\text { and others to engage the Department of Bantu Education failed. Mobilising under the banner of the South African Student Movement, youths } \\
\text { and activists marched to Orlando Stadium on the morning of } 16 \text { June 1976. The students met a police contingent along the way. Altercations } \\
\text { ensued and turned violent. Hector Pieterson, a 13-year-old student, was among the first students to be shot dead by the police at the gates } \\
\text { of Orlando West High School. The battles spread. Police reinforcements were deployed and used teargas and live ammunition. The Soweto } \\
\text { uprising quickly spread to other areas in the country. The Cillié Commission recorded } 575 \text { deaths by the end of February } 1977 \text {. }\end{array}$} \\
\hline
\end{tabular}




\begin{tabular}{|c|c|c|c|c|c|c|c|c|c|}
\hline Inquiry name & Date & Reference & Type of inquiry & Chairperson & \multicolumn{5}{|c|}{ Commissioner(s) } \\
\hline \multirow{4}{*}{$\begin{array}{l}\text { Commission of } \\
\text { Inquiry into Reporting } \\
\text { on Security Matters } \\
\text { regarding the South } \\
\text { African Defence } \\
\text { Force and the South } \\
\text { African Police }\end{array}$} & Established: Dec 1979 & \multirow{2}{*}{ RP-52/1980 } & \multirow{2}{*}{$\begin{array}{l}\text { Judicial Commission } \\
\text { of Inquiry }\end{array}$} & Marthinus T Steyn & $\begin{array}{l}\text { DAS } \\
\text { Herbst }\end{array}$ & $\begin{array}{l}\text { NN } \\
\text { Webster }\end{array}$ & $\begin{array}{l}\text { KPC } \\
\text { Wilkau }\end{array}$ & \begin{tabular}{l|l} 
LC \\
Masterson
\end{tabular} & KH Fisher \\
\hline & Finalised: 1980 & & & Puisne judge & & & & & \\
\hline & Terms of reference & \multicolumn{8}{|c|}{$\begin{array}{l}\text { 'To inquire into and to make recommendations about news media reporting of Defence Matters, the effectiveness of the Police Act, necessity } \\
\text { of amending legislation, formulation of proposed amendments to the Defence Act /Police Act.' }\end{array}$} \\
\hline & Context & \multicolumn{8}{|c|}{$\begin{array}{l}\text { Post Soweto, the Nationalist Party government increasingly advanced a 'total onslaught' theory of politics. State security, so the argument } \\
\text { went, was increasingly being challenged by a focused, communist-inspired strategy. An investigation into press freedom was considered } \\
\text { necessary so as to consider the desirability of prohibitions on the unauthorised disclosure of information relating to activities performed by the } \\
\text { armed forces. A few years later Judge Steyn probed press freedom more generally. }\end{array}$} \\
\hline
\end{tabular}

\begin{tabular}{|c|c|c|c|c|c|}
\hline \multirow{4}{*}{$\begin{array}{l}\text { Report of the } \\
\text { Commission of Inquiry } \\
\text { into the Violence } \\
\text { which occurred on } 29 \\
\text { October } 1983 \text { at the } \\
\text { University of Zululand } \\
\text { (Vol. } 1 \text { \& 2) }\end{array}$} & Established: Nov 1983 & \multirow[b]{2}{*}{ RP 80} & \multirow{2}{*}{$\begin{array}{l}\text { Departmental } \\
\text { committee of inquiry - } \\
\text { Dept. of Education }\end{array}$} & Anthony J Middleton & \\
\hline & Finalised: Feb 1985 & & & $\begin{array}{l}\text { Prof. Dept. Criminal Law, } \\
\text { UNISA }\end{array}$ & \\
\hline & Terms of reference & \multicolumn{4}{|c|}{$\begin{array}{l}\text { 'To inquire into, report upon, and make recommendations regarding the violence at the University of Zululand on } 29 \text { October } 1983 \text { and the } \\
\text { causes thereof.' }\end{array}$} \\
\hline & Context & \multicolumn{4}{|c|}{$\begin{array}{l}\text { A clash on campus between the Inkatha Movement and students supporting the United Democratic Front (UDF) occurred. UDF supporters } \\
\text { drew attention to what they called 'morally distasteful tribalism' at the university. Casualties: five persons killed and an estimated } 100 \text { injured. }\end{array}$} \\
\hline
\end{tabular}

\begin{tabular}{|c|c|c|c|c|c|c|c|}
\hline \multirow{4}{*}{$\begin{array}{l}\text { Report of the } \\
\text { Commission } \\
\text { appointed to inquire } \\
\text { into the Incident } \\
\text { which occurred on } \\
21 \text { March } 1985 \text { at } \\
\text { Uitenhage }\end{array}$} & Established: Mar 1985 & \multirow{2}{*}{$\mathrm{RP} 74$} & \multirow{2}{*}{$\begin{array}{l}\text { Judicial Commission } \\
\text { of Inquiry }\end{array}$} & DDV Kannemeyer & $\mathrm{CDHO} \mathrm{Nel}$ & PA du Rand & JM Kula \\
\hline & Finalised: Jun 1985 & & & Judge & Advocate & Dept. of Justice & Interpreter \\
\hline & Terms of reference & \multicolumn{6}{|c|}{ 'To investigate all the factual circumstances regarding the incident at Uitenhage.' } \\
\hline & Context & \multicolumn{6}{|c|}{$\begin{array}{l}\text { A crowd gathered to attend the funeral of people who died because of police action against rioters from 8-10 March } 1985 \text {. As the funeral } \\
\text { was prohibited, the police proceeded to disperse the crowd with lethal force. }\end{array}$} \\
\hline
\end{tabular}

\begin{tabular}{|c|c|c|c|c|c|}
\hline \multirow{4}{*}{$\begin{array}{l}\text { The Commission of } \\
\text { Inquiry into the } 1986 \\
\text { Unrest and Alleged } \\
\text { Mismanagement in } \\
\text { KwaNdebele }\end{array}$} & Established: 1986 & \multirow{2}{*}{ RP 120/1992 } & \multirow{2}{*}{ Commission of Inquiry } & Benjamin J Parsons & \\
\hline & Finalised: 1992 & & & & \\
\hline & Terms of reference & \multicolumn{4}{|c|}{$\begin{array}{l}\text { 'Inquire into and report on any mismanagement that has occurred in the Governmental Department of KwaNdebele, the KwaNdebele } \\
\text { Corporation and KwaNdebele Utility Company, and to determine steps to halt such mismanagement or to prevent their occurrence.' }\end{array}$} \\
\hline & Context & \multicolumn{4}{|c|}{ Report 2 of the Parsons Commission dealt specifically with police functions and police excesses within the Department of Law and Order. } \\
\hline
\end{tabular}




\begin{tabular}{|c|c|c|c|c|c|}
\hline Inquiry name & Date & Reference & Type of inquiry & Chairperson & Commissioner(s) \\
\hline \multirow{4}{*}{$\begin{array}{l}\text { Report of the } \\
\text { Commission of } \\
\text { Enquiry into the } \\
\text { cause of the unrest } \\
\text { in Venda during } \\
\text { August } 1988 \text { and the } \\
\text { investigation of ritual } \\
\text { murders }\end{array}$} & Established: Aug 1988 & & \multirow{2}{*}{$\begin{array}{l}\text { Judicial Commission } \\
\text { of Inquiry }\end{array}$} & Daniël JH le Roux & \\
\hline & Finalised: 1989 & & & Judge & \\
\hline & Terms of reference & \multicolumn{4}{|c|}{$\begin{array}{l}\text { To investigate and report upon: } \\
\text { 'The causes of the present unrest, school boycotts, and work stoppages in Venda, with reference inter alia to the circumstances surrounding } \\
\text { the investigation of so-called ritual murders committed during 1988.' }\end{array}$} \\
\hline & Context & \multicolumn{4}{|c|}{$\begin{array}{l}\text { School principal Mr Makhavhu made a speech and implied that teacher Mikhosi James Mavhina had been ritually murdered. The pupils } \\
\text { started a school boycott hoping to ascertain the truth of their teacher's death. However, the school boycott developed into a wave of unrest } \\
\text { to which the police responded. }\end{array}$} \\
\hline
\end{tabular}

\begin{tabular}{|c|c|c|c|c|c|}
\hline \multirow{4}{*}{$\begin{array}{l}\text { Report of the } \\
\text { Commission of } \\
\text { Enquiry into the } \\
\text { incidents at Sebokeng, } \\
\text { Boipatong, Lekoa, } \\
\text { Sharpeville and Evaton } \\
\text { on } 26 \text { March } 1990\end{array}$} & Established: 1990 & \multirow{2}{*}{ G68 E2 15/90 } & \multirow{2}{*}{$\begin{array}{l}\text { Judicial Commission } \\
\text { of Inquiry }\end{array}$} & RJ Goldstone & \\
\hline & Finalised: 1990 & & & Judge & \\
\hline & Terms of reference & \multicolumn{4}{|c|}{$\begin{array}{l}\text { 'To inquire and report upon all the factual circumstances concerning the incidents that took place on } 26 \text { March } 1990 \text { during which people } \\
\text { were injured and killed.' }\end{array}$} \\
\hline & Context & \multicolumn{4}{|c|}{$\begin{array}{l}\text { Police opened fire on a procession in Sebokeng that challenged a restriction order. Twelve people were killed and } 281 \text { injured. The } \\
\text { commanding officer was criticised for not firing warning shots. The majority of those shot had wounds to the back of the head or the back. } \\
\text { The judge determined the force to be 'disproportional'. }\end{array}$} \\
\hline
\end{tabular}

\begin{tabular}{|c|c|c|c|c|c|}
\hline \multirow{4}{*}{$\begin{array}{l}\text { Report of the } \\
\text { Commission of Inquiry } \\
\text { into certain Alleged } \\
\text { Murders }\end{array}$} & Established: Feb 1990 & \multirow{2}{*}{ RP 109/1990 } & \multirow{2}{*}{$\begin{array}{l}\text { Judicial Commission } \\
\text { of Inquiry }\end{array}$} & \multirow{2}{*}{$\begin{array}{l}\text { LTC Harms } \\
\text { Judge }\end{array}$} & \\
\hline & Finalised: Sept 1990 & & & & \\
\hline & Terms of reference & \multicolumn{4}{|c|}{$\begin{array}{l}\text { (1) 'To inquiry into and report on the alleged occurrence of murders and other unlawful acts of violence committed in the Republic of South } \\
\text { Africa - with political aims. } \\
\text { (2) If it can be found that such murders and acts of violence were committed, to report on: } \\
\text { I) who or what bodies, institutions or organisations commit, cause or instruct to be committed such murders or acts of violence as } \\
\text { principal offender, accomplice or accessory after the fact, or have done so in the past; and } \\
\text { II) who finances or has financed any such person, body, institution or organisation. } \\
\text { (3) To inquire into and report on any other matter which, in their opinion, is relevant to the foregoing.' }\end{array}$} \\
\hline & Context & \multicolumn{4}{|c|}{$\begin{array}{l}\text { Claims regarding the existence of hit squads based at a farm outside Pretoria snowballed after allegations made by Alfred Nofomela, a } \\
\text { convicted person on death row. Dirk Coetzee corroborated these allegations. The commission proceeded to investigate two networks: the } \\
\text { SAP death squad at Vlakplaas and the Civil Cooperation Bureau of the South African Defence Force (SADF). }\end{array}$} \\
\hline
\end{tabular}




\begin{tabular}{|c|c|c|c|c|c|c|}
\hline Inquiry name & Date & Reference & Type of inquiry & Chairperson & \multicolumn{2}{|c|}{ Commissioner(s) } \\
\hline \multirow{4}{*}{$\begin{array}{l}\text { Report of } \\
\text { Commission of } \\
\text { Inquiry into Activities } \\
\text { of Police and Military } \\
\text { Relative to the } \\
\text { Teachers' strike }\end{array}$} & Established: Sept 1993 & \multirow{2}{*}{ E2 } & \multirow{2}{*}{$\begin{array}{l}\text { Judicial Commission } \\
\text { of Inquiry }\end{array}$} & AVM Lugaju & TC Mabaso & LV Makaba \\
\hline & Finalised: 1994 & & & Magistrate & Magistrate & Magistrate \\
\hline & Terms of reference & \multicolumn{5}{|c|}{$\begin{array}{l}\text { 'To inquire into and report upon: } \\
\text { (1) Factors leading to police presence in the Head Office of the Education Department; } \\
\text { (2) The events that led to the alleged assault on teachers; } \\
\text { (3) The factors necessitating the Police and Defence Force to join forces against the teachers; } \\
\text { The consequences caused by the strike and inconveniences.' }\end{array}$} \\
\hline & Context & \multicolumn{5}{|c|}{$\begin{array}{l}\text { After a dispute between the SA Democratic Teachers' Union, Transkei Region, and the Department of Education, the disgruntled teachers } \\
\text { staged a sit-in at the Head Office of the Department of Education. The police intervened. }\end{array}$} \\
\hline
\end{tabular}

\begin{tabular}{|c|c|c|c|c|c|c|c|}
\hline \multirow{9}{*}{$\begin{array}{l}\text { Commission of } \\
\text { Inquiry regarding } \\
\text { the Prevention of } \\
\text { Public Violence and } \\
\text { Intimidation }\end{array}$} & Established: Oct 1991 & \multirow{2}{*}{$\begin{array}{l}\text { Standing Judicial } \\
\text { Commission of Inquiry }\end{array}$} & \multirow{2}{*}{\begin{tabular}{|l|} 
RJ Goldstone \\
Judge
\end{tabular}} & \multirow{2}{*}{$\begin{array}{l}\text { DJ Rossouw } \\
\text { Advocate }\end{array}$} & \multirow{2}{*}{$\begin{array}{l}\text { Solly Sithole } \\
\text { Advocate }\end{array}$} & \multirow[t]{2}{*}{ Lillian Baqwa } & \multirow[t]{2}{*}{ Gert Steyn } \\
\hline & Finalised: Apr 1994 & & & & & & \\
\hline & Terms of reference & \multicolumn{6}{|c|}{$\begin{array}{l}\text { 'To inquire into the phenomenon of public violence and intimidation in the Republic, the nature and causes thereof, and what persons were } \\
\text { involved therein; } \\
\text { inquire into any steps that should be taken in order to prevent public violence and intimidation; and } \\
\text { to make recommendations to the State President in respect of public violence and intimidation.' }\end{array}$} \\
\hline & Context & \multicolumn{6}{|c|}{$\begin{array}{l}\text { The unbanning of the liberation movements paved the way for a negotiated settlement. However, political violence of a complex nature } \\
\text { posed serious obstacles for the holding of the first democratic elections in April 1994. The commission was tasked with the responsibility to } \\
\text { investigate a wide range of incidences and types of violence. In its three years of existence it submitted } 47 \text { separate reports. Below is a list of } \\
\text { those reports that had a specific bearing on the police. }\end{array}$} \\
\hline & \multicolumn{7}{|c|}{ Reports of the committees appointed by the Commission of Inquiry regarding the Prevention of Public Violence and Intimidation: } \\
\hline & \multirow{2}{*}{ 93/5489 } & \multicolumn{6}{|c|}{ The violence at Mooi River on 3 and 4 Dec 1991 to 19 Feb 1992} \\
\hline & & \multicolumn{6}{|c|}{ 'To inquire into, and report upon the violence at Mooi River, and make recommendations to prevent further violence.' } \\
\hline & \multirow{2}{*}{ 92/10136 } & \multicolumn{6}{|l|}{ Further report on the violence at Mooi River } \\
\hline & & \multicolumn{6}{|c|}{ 'To inquire into, and report upon the violence at Mooi River, and make recommendations to prevent further violence.' } \\
\hline
\end{tabular}




\begin{tabular}{|c|c|c|c|c|c|}
\hline Inquiry name & Date & Reference & Type of inquiry & Chairperson & Commissioner(s) \\
\hline \multirow{15}{*}{$\begin{array}{l}\text { Commission of } \\
\text { Inquiry regarding } \\
\text { the Prevention of } \\
\text { Public Violence and } \\
\text { Intimidation }\end{array}$} & \multicolumn{5}{|c|}{ Reports of the committees appointed by the Commission of Inquiry regarding the Prevention of Public Violence and Intimidation (continued): } \\
\hline & \multirow{2}{*}{ C1010 } & \multicolumn{4}{|c|}{$\begin{array}{l}\text { The Commission of Inquiry regarding the Prevention of Public Violence and Intimidation has the honour to present a report on the Bisho } \\
\text { incident on } 7 \text { September } 1992\end{array}$} \\
\hline & & \multicolumn{4}{|c|}{$\begin{array}{l}\text { To inquire into and report upon: } \\
\text { 'The nature and organisation of the march and the events immediately preceding the shooting; and the shooting itself.' }\end{array}$} \\
\hline & & \multicolumn{4}{|c|}{$\begin{array}{l}\text { The Commission of Inquiry regarding the Prevention of Public Violence and Intimidation has the honour to present its report on the planning or } \\
\text { instigation of acts of violence by members of the South African Police in the Vaal Area }\end{array}$} \\
\hline & C1013 & \multicolumn{4}{|c|}{$\begin{array}{l}\text { To inquire into and report on: } \\
\text { 'police accountability and police methods; and } \\
\text { allegations of planned and instigated violence by the police.' }\end{array}$} \\
\hline & & \multicolumn{4}{|c|}{ Report on the Inquiry conducted by the Committee of Inquiry into the violence at Tokoza } \\
\hline & C1015 & \multicolumn{4}{|c|}{$\begin{array}{l}\text { 'Inquire into the phenomena and incidents of public violence and intimidation in Tokoza and three incidents which gave rise to the considerable } \\
\text { escalation of violence: } \\
\text { The assassination of } 18 \text { hostel dwellers; } \\
\text { The murder of Sam Ntuli; } \\
\text { The assassination of Africans near the Natalspruit Hospital.' }\end{array}$} \\
\hline & & \multicolumn{4}{|c|}{ Report by the Commission's Natal Investigation Team into allegations of the presence of Renamo soldiers in KwaZulu } \\
\hline & 93/10567 & \multicolumn{4}{|c|}{$\begin{array}{l}\text { 'To inquire into, and report upon the allegation of Renamo soldiers in KwaZulu, and the alleged training of KwaZulu Police in hit squad } \\
\text { techniques.' }\end{array}$} \\
\hline & & \multicolumn{4}{|c|}{ Report of the Committee conducting a preliminary investigation into the activities of the Azanian People's Liberation Army (APLA) } \\
\hline & 93/10727 & \multicolumn{4}{|c|}{$\begin{array}{l}\text { 'Conduct a preliminary investigation and to hear evidence and to receive submissions from relevant persons on the location of APLA camps, } \\
\text { arms, ammunition, personnel and on its operational activities.' }\end{array}$} \\
\hline & & \multicolumn{4}{|c|}{ Final Report to the Commission of inquiry regarding the Prevention of Public Violence and Intimidation } \\
\hline & 93/10565 & \multicolumn{4}{|c|}{$\begin{array}{l}\text { Revised draft of the proposed bill to prevent public violence and intimidation at mass demonstrations, marches, and picketing in } \\
\text { South Africa }\end{array}$} \\
\hline & & \multicolumn{4}{|c|}{ Violence at Mossel Bay during July 1993} \\
\hline & & \multicolumn{4}{|c|}{ 'To inquire into and report upon the violence at Mossel Bay.' } \\
\hline
\end{tabular}




\begin{tabular}{|c|c|c|c|c|c|}
\hline Inquiry name & Date & Reference & Type of inquiry & Chairperson & Commissioner(s) \\
\hline \multirow{15}{*}{$\begin{array}{l}\text { Commission of } \\
\text { Inquiry regarding } \\
\text { the Prevention of } \\
\text { Public Violence and } \\
\text { Intimidation }\end{array}$} & \multicolumn{5}{|c|}{ Reports of the committees appointed by the Commission of Inquiry regarding the Prevention of Public Violence and Intimidation (continued): } \\
\hline & \multirow[b]{2}{*}{$94 / 16225$} & \multicolumn{4}{|c|}{ South Africa Committee of Inquiry into Police Action During the Right-Wing Invasion of the World Trade Centre in June 1993 (Kemptonpark). } \\
\hline & & \multicolumn{4}{|c|}{$\begin{array}{l}\text { 'To inquire whether the officer in charge and the members of the South African police were properly attributed to their task; and whether the } \\
\text { available members were efficiently utilized. } \\
\text { To inquire and report upon the reasons found for the ineffective actions of the police during the incident as already indicated by the Goldstone } \\
\text { Commission; and to recommend measures that can be taken to prevent a recurrence of the incident.' }\end{array}$} \\
\hline & \multirow{2}{*}{$94 / 3545$} & \multicolumn{4}{|c|}{ Report on the shooting incident at Katlehong on Sunday, 9 January 1994} \\
\hline & & \multicolumn{4}{|c|}{ 'Inquire into, report upon, and make recommendations on the shooting incident at Katlehong on Sunday, 9 January 1994.' } \\
\hline & \multirow[b]{2}{*}{$94 / 13174$} & \multicolumn{4}{|c|}{ Report on the attack on the Power Park Squatter Camp on 27 July 1993} \\
\hline & & \multicolumn{4}{|c|}{$\begin{array}{l}\text { 'To investigate the alleged role of the SAP in an attack by residents of Nancefield Hostel on residents of Power Park in Soweto; } \\
\text { With special reference to the steps taken to curb assailants and or protect those attacked.' }\end{array}$} \\
\hline & \multirow[b]{2}{*}{$94 / 9720$} & \multicolumn{4}{|c|}{ Inquiry into the shooting incidents which took place in the centre of Johannesburg on 28 March 1994} \\
\hline & & \multicolumn{4}{|c|}{$\begin{array}{l}\text { 'The Commission made no findings during the preliminary report and suggested that it would determine the terms of reference when further } \\
\text { evidence and statements were available.' }\end{array}$} \\
\hline & & \multicolumn{4}{|c|}{ Criminal political violence by elements within the South African Police, the KwaZulu Police and Inkatha Freedom Party } \\
\hline & $94 / 6969$ & \multicolumn{4}{|c|}{$\begin{array}{l}\text { 'To investigate allegations against SAP members of Unit C10 at Vlakplaas. } \\
\text { To investigate KwaZulu Police hit squads. } \\
\text { To investigate the distribution of arms and ammunition to Inkatha members.' }\end{array}$} \\
\hline & & \multicolumn{4}{|c|}{ Report on attacks on members of the South African Police } \\
\hline & $94 / 9721$ & \multicolumn{4}{|c|}{$\begin{array}{l}\text { 'To ascertain the circumstance under which policemen have been killed or injured since } 17 \text { July 1991; } \\
\text { to identify any persons or organisations directly or indirectly responsible for the killings and injuries; and } \\
\text { to recommend steps which should be taken to prevent or curb any recurrence of such killings.' }\end{array}$} \\
\hline & & \multicolumn{4}{|c|}{ Final report of the Goldstone Commission } \\
\hline & $94 / 20162$ & \multicolumn{4}{|c|}{$\begin{array}{l}\text { 'This report was published to release the final reports on specific matters: } \\
\text { a) Boipatong; } \\
\text { b) Shooting incidents in Johannesburg (94/9720); } \\
\text { c) Police involvement with violence (94/6969); } \\
\text { The murder of IFP members (94/3545).' }\end{array}$} \\
\hline
\end{tabular}




\begin{tabular}{|c|c|c|c|c|c|}
\hline Inquiry name & Date & Reference & Type of inquiry & Chairperson & Commissioner(s) \\
\hline \multirow{4}{*}{$\begin{array}{l}\text { Commission of } \\
\text { Inquiry into the } \\
\text { incidents that led } \\
\text { to the violence } \\
\text { in the former } \\
\text { Bophuthatswana } \\
\text { on } 11 \text { March 1994, } \\
\text { and the deaths that } \\
\text { occurred as a result } \\
\text { thereof }\end{array}$} & Established: 1994 & \multirow{2}{*}{ RP 114} & \multirow{2}{*}{$\begin{array}{l}\text { Judicial Commission } \\
\text { of Inquiry }\end{array}$} & PH Tebbutt & TK Gura \\
\hline & Finalised: Mar 1998 & & & Judge & \\
\hline & Terms of reference & \multicolumn{4}{|c|}{$\begin{array}{l}\text { 'To inquire into and report upon: } \\
\text { (1) The identity of the deceased; } \\
\text { (2) The circumstances of each death; } \\
\text { (3) The cause or likely cause of each death; } \\
\text { (4) Whether or not each death was due to [an] act involving or amounting to an offence on the part of a person(s), and if so what the identity } \\
\text { of such a person(s) is.' }\end{array}$} \\
\hline & Context & \multicolumn{4}{|c|}{$\begin{array}{l}\text { After } 1991 \text { the question as to whether Bophuthatswana should be re-incorporated into South Africa became hotly contested, resulting in } \\
\text { wildcat strikes, civil unrest and pitched battles between workers, students and the homeland government. At some point dissidents within } \\
\text { the police and defence force favoured integration. Concerns among public servants grew as President Lucas Mangope announced that his } \\
\text { administration would not participate in the } 1994 \text { general elections. Right-wing paramilitary units (the Afrikaner Weerstandsbeweging [AWB] } \\
\text { and Afrikaner Volksfront) offered to assist in repressing the uprising. Contingents of armed white men arrived on Friday } 11 \text { March } 1994 \text {. Their } \\
\text { presence was met with great concern in Defence Force circles. Disorder spread. Members of the AWB were instructed to leave and on their } \\
\text { way out shot at citizens on the street. Three members of the AWB were shot dead by a police officer. The South African army and police } \\
\text { were called to stabilise matters. Mangope was ordered to step down and the South African government took over the administration. The } \\
\text { commission identified } 60 \text { deceased persons who allegedly died in the uprisings at Mmabatho/Mafikeng. }\end{array}$} \\
\hline
\end{tabular}

\begin{tabular}{|c|c|c|c|c|c|c|}
\hline \multirow{4}{*}{$\begin{array}{l}\text { Report by the South } \\
\text { African Human Rights } \\
\text { Commission } \\
\text { Inquiry into racism } \\
\text { in the SAPS Vryburg } \\
\text { District }\end{array}$} & Established: 1999 & \multirow{2}{*}{ 2000/12816 } & \multirow{2}{*}{ Statutory Commission } & Dr Nyameko B Pityana & Faith P Tlakula & Leon Wessels \\
\hline & Finalised: Nov 1999 & & & Advocate & Advocate & Advocate \\
\hline & Terms of reference & \multicolumn{5}{|c|}{$\begin{array}{l}\text { (1) 'To investigate incidents of racism or racial discrimination, if any, in the Vryburg District of SAPS; } \\
\text { (2) To examine how these manifest themselves; } \\
\text { (3) To establish the underlying causes; } \\
\text { (4) To assess how they impact on effective policing and the observance of fundamental rights; } \\
\text { (5) To note what steps were taken at all levels to address these problems; and } \\
\text { To make findings and recommendations, as appropriate.' }\end{array}$} \\
\hline & Context & \multicolumn{5}{|c|}{$\begin{array}{l}\text { Allegations of racial tension at the Vryburg police station came to the attention of the commission. It launched an inquiry that assessed } \\
\text { evidence relating to racial basis in management practices, the allocation of offices, personnel transfers and the treatment of black officers as } \\
\text { well as black members of the public by the police. }\end{array}$} \\
\hline
\end{tabular}




\begin{tabular}{|c|c|c|c|c|c|}
\hline Inquiry name & Date & Reference & Type of inquiry & Chairperson & Commissioner(s) \\
\hline \multirow{4}{*}{$\begin{array}{l}\text { Commission of } \\
\text { Inquiry into the } \\
\text { mandate and } \\
\text { location of the } \\
\text { Directorate of } \\
\text { Special } \\
\text { Operations ('the } \\
\text { DSO') }\end{array}$} & Established: Apr 2005 & \multirow{2}{*}{ G 68 G 31014/2008 } & \multirow{2}{*}{$\begin{array}{l}\text { Judicial Commission } \\
\text { of Inquiry }\end{array}$} & Sisi Khampepe & \\
\hline & Finalised: Feb 2006 & & & Judge & \\
\hline & Terms of reference & \multicolumn{4}{|c|}{$\begin{array}{l}\text { 'To inquire into, make findings, report upon, and make recommendations regarding: } \\
\text { (1) The rationale behind the establishment of the DSO and its location; } \\
\text { (2) The mandate of the DSO and an evaluation of the implementation thereof; } \\
\text { (3) The system for management, control, communication, oversight and accountability by the DSO; } \\
\text { (4) The accountability effectiveness, efficiency and oversight in respect of the intelligence operations of the DSO; } \\
\text { (5) The Constitutional and legislative mandate of the SAPS and the intelligence agencies, with reference to their roles in respect of organised } \\
\text { and high level priority crimes; } \\
\text { (6) The system for coordinating systems that exist between the SAPS and the intelligence agencies on the one hand and the DSO on the } \\
\text { Other; } \\
\text { (7) The efficacy of coordinating systems that exist between DSO and the SAPS; } \\
\text { (8) The need to review present legislative framework and make recommendations on: } \\
\text { Remedial actions } \\
\text { Options regarding a suitable location for the DSO'. }\end{array}$} \\
\hline & Context & \multicolumn{4}{|c|}{$\begin{array}{l}\text { The DSO was established to curb organised crime. However, conflict soon arose between the DSO and SAPS. The DSO formed part of the } \\
\text { National Prosecuting Authority and shared an overlapping mandate with the SAPS. Both were unwilling to cooperate. }\end{array}$} \\
\hline \multirow{4}{*}{$\begin{array}{l}\text { South African } \\
\text { Human Rights } \\
\text { Commission report: } \\
\text { In the matter } \\
\text { between Council for } \\
\text { the Advancement of } \\
\text { the SA Constitution } \\
\text { and South African } \\
\text { Police Service }\end{array}$} & Established: 2011 & \multirow{2}{*}{ FS/2011/0009 } & \multirow{2}{*}{ Statutory Commission } & Adv. ML Mushwana & \\
\hline & Finalised: Oct 2012 & & & Advocate & \\
\hline & Terms of reference & \multicolumn{4}{|c|}{ 'To investigate the alleged violation of a citizen's human rights during a public protest.' } \\
\hline & Context & \multicolumn{4}{|c|}{$\begin{array}{l}\text { During a service delivery protest in Ficksburg the police fired rubber bullets. They then went on to assault Andries Tatane, who died of his } \\
\text { injuries. The commission investigated police conduct and crowd control at the public protest. }\end{array}$} \\
\hline
\end{tabular}




\begin{tabular}{|c|c|c|c|c|c|}
\hline Inquiry name & Date & Reference & Type of inquiry & Chairperson & Commissioner(s) \\
\hline \multirow{4}{*}{$\begin{array}{l}\text { Report of the } \\
\text { Commission } \\
\text { of Inquiry into } \\
\text { Allegations } \\
\text { of Police inefficiency } \\
\text { and a Breakdown in } \\
\text { Relations between } \\
\text { SAPS and the } \\
\text { Community of } \\
\text { Khayelitsha }\end{array}$} & Established: Aug 2012 & & \multirow{2}{*}{$\begin{array}{l}\text { Judicial Commission } \\
\text { of Inquiry }\end{array}$} & Catherine O'Regan & Vusumzi Pikoli \\
\hline & Finalised: Aug 2014 & & & Judge & Advocate \\
\hline & Terms of reference & \multicolumn{4}{|c|}{$\begin{array}{l}\text { 'To investigate complaints concerning allegations of: } \\
\text { (1) Inefficiency of the SAPS stationed at Khayelitsha; and } \\
\text { (2) The breakdown in relations between the Khayelitsha community and members of the SAPS stationed at police stations in Khayelitsha; } \\
\text { (3) Investigate the reasons for, and causes of, the inefficiency and breakdown in relations; } \\
\text { Compile a report containing the findings and recommendations to alleviate and remedy the concerns.' }\end{array}$} \\
\hline & Context & \multicolumn{4}{|c|}{$\begin{array}{l}\text { Non-governmental organisations lodged complaints concerning inefficiency, poor service delivery and a breakdown of relations between the } \\
\text { Khayelitsha community and police members. The premier of the Western Cape then established a commission of inquiry into matters. }\end{array}$} \\
\hline
\end{tabular}

\begin{tabular}{|c|c|c|c|c|c|}
\hline \multirow{4}{*}{$\begin{array}{l}\text { Marikana } \\
\text { Commission of } \\
\text { Inquiry } \\
\text { Report on matters of } \\
\text { public, national and } \\
\text { international concern } \\
\text { arising out of the } \\
\text { tragic } \\
\text { Incidents at the } \\
\text { Lonmin mine in } \\
\text { Marikana, in the } \\
\text { North West } \\
\text { Province }\end{array}$} & Established: Aug 2012 & \multirow{2}{*}{$\begin{array}{l}\text { Judicial Commission } \\
\text { of Inquiry }\end{array}$} & Ian G Farlam & Pingla D Hemraj SC & Bantubonke Tokota \\
\hline & Finalised: Mar 2015 & & Judge & Advocate & Advocate \\
\hline & Terms of reference & \multicolumn{4}{|c|}{$\begin{array}{l}\text { 'To inquire into, make finding, report upon, and make recommendations concerning: } \\
\text { (1) The conduct of Lonmin PLC; } \\
\text { (2) The conduct of the SAPS; } \\
\text { (3) The conduct of the Association of Mineworkers and Construction Union (AMCU), its members and officials; } \\
\text { (4) Whether the role played by the Dept. of Mineral Resources or any other government department or agency was appropriate in the } \\
\text { circumstances; } \\
\text { Whether individual or group conduct promoted a situation of conflict, and gave rise to the incident.' }\end{array}$} \\
\hline & Context & \multicolumn{4}{|c|}{$\begin{array}{l}\text { A labour dispute that started with rock drillers at the Lonmin platinum mine spread and on } 10 \text { August } 20123000 \text { workers engaged in an } \\
\text { unprotected strike. During the next few days the conflict unfolded. Various incidents of intimidation and violence occurred that left } 10 \text { people } \\
\text { dead. A standoff between a large group of miners assembled on a hill outside the mine and a waiting police cordon resulted in the police } \\
\text { opening fire with automatic weapons. }\end{array}$} \\
\hline
\end{tabular}




\section{South African inquiries into policing \\ Centre of Criminology, UCT}

Annie Kok \& Elrena van der Spuy

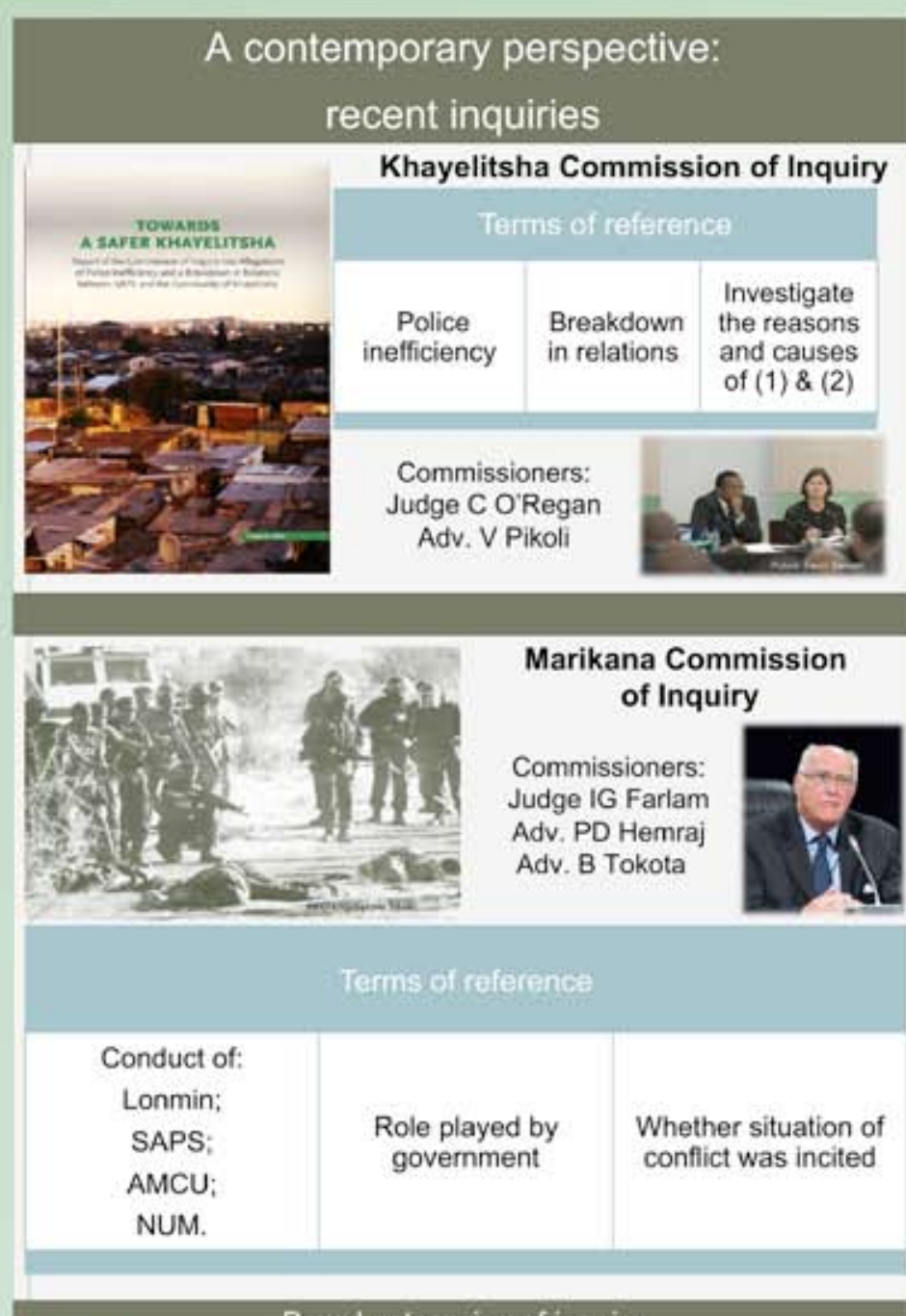

Broad categories of inquiry

Administrative inquiries

Riots/social disturbances/protest-related inquiries

Inquiries into police conduct

Other inquiries

\section{Virtues of historical perspective}

1913 Judge JW Wessels

1913 Judge $M$ de Vilitiers

1914 WH Solomon

1918 TL Graham

1918 Judge A Stockenstróm

1919 GJ Boyes

1920 CW Schweizer

1921 AW Roberts

1923 AW Roberts

1925 AGE Pienaar

1925 Cle Water

1929 D de Waal

1936 C Lansdown

1938 DL Smit

1914 Judge SHE Elitiot

1943 Judge CE Morris

1948 HA Fagan

1949 F vid Heever

1950 J de V Louw

1950 OH Hoexter

1951 A Eyles

1954 JHBasson

1958 Judge A v S Centilivres

1960 PJWessels

1960 M Diemont

1963 JH Snyman

1971 HJ Potgieter

1975 JH Snyman

1980 PM Collie

1980 MT Steyn

1985 A.J Middloton

1985 Judge DDV Kannemayer

1992 BJ Parsons

1989 Judge DJH le Roux

1990 Judge RJ Goldstone

1990 Judge LTC Harms

1994 Judge AVM Lugaju

1991-1994 Goldstone Commission

1998 Judge PH Tobbutt

1999 Adv. NB Pityana

2006 Judge S Khampepe

2012 Adv. ML Mushwana

2014 Judge C O'Regan

2015 Judge IG Farlam
Strike Riot Foroe Casualties

Efficiency

Strike Force Casualties

Administrative

Strike Administrative

Protest Force Casualties

Strike Force Casualtes

Protest Force Casualties

Protest Force Casualties

Protest Force Casualties Strike Riot

Administrative Efficiency

Protest Casualtes

Administrative Efficiency Relations

Liquor raids Force Casuattes

Ript Force

Riot Force Casualties

Riot Protest Casualties

Riot Force Casualties

Riot Liquor raids Casualties

Corruption

Protest Riot Casualties

Administrative

Riot Casualties

Protest Force Casualties Strike

Protest Force Casualties Strike

Protest Force Casualties

Administrative

Administrative

Protest

Protest Force Casualties

Administrative

Riot Casualties

Force Casualties

Efficiency

Protest Strike

Protest Force Casualties

Corruption

Strike

Various

Riot Force Casualties

Efficiency

Efficiency Administrative

Efficiency Protest

Efficiency Administrative Relations

Protest Force Casualties Strike
Thinking critically

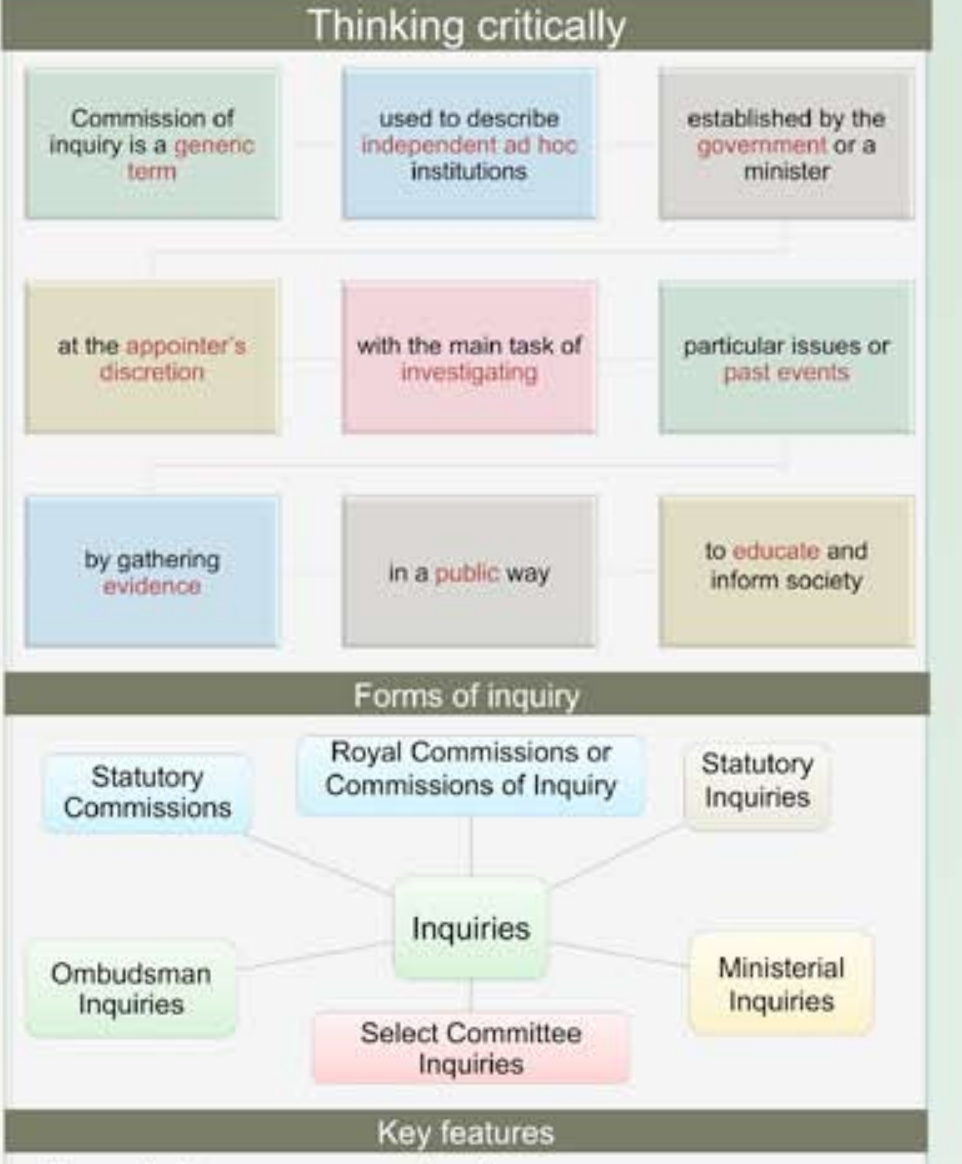

- Terms of reference: narrow or broad

- Inquisitorial and/or advisory: forward looking or backward looking

- Use of expert evidence

- Recommending technical and/or systemic changes

\section{Functions}

- Legitimating state power

- Retrospective learning

- Restoring public confidence

- Lesson drawing

- Blame avoidance

- Preventing recurrences

Outcomes

Outcomes are uncertain and context dependent

anniekok3@gmail com

\section{Contact Information}

